\title{
Simulated high-latitude soil thermal dynamics during the past 4 decades
}

\author{
S. Peng ${ }^{1,2}$, P. Ciais ${ }^{2}$, G. Krinner ${ }^{1}$, T. Wang ${ }^{1,2}$, I. Gouttevin ${ }^{1,3}$, A. D. McGuire ${ }^{4}$, D. Lawrence ${ }^{5}$, E. Burke ${ }^{6}$, X. Chen ${ }^{7}$, \\ B. Decharme ${ }^{8}$, C. Koven ${ }^{9}$, A. MacDougall ${ }^{10}$, A. Rinke ${ }^{11,12}$, K. Saito ${ }^{13}$, W. Zhang ${ }^{14}$, R. Alkama ${ }^{8}$, T. J. Bohn ${ }^{15}$, \\ C. Delire ${ }^{8}$, T. Hajima ${ }^{13}$, D. Ji ${ }^{11}$, D. P. Lettenmaier ${ }^{7}$, P. A. Miller ${ }^{14}$, J. C. Moore ${ }^{11}$, B. Smith ${ }^{14}$, and T. Sueyoshi ${ }^{16,13}$ \\ ${ }^{1}$ UJF-Grenoble 1/CNRS, Laboratoire de Glaciologie et Géophysique de l'Environnement (LGGE), 38041 Grenoble, France \\ ${ }^{2}$ Laboratoire des Sciences du Climat et de 1'Environnement (LSCE), CEA-CNRS-UVSQ, 91191 Gif-sur-Yvette, France \\ ${ }^{3}$ Irstea, UR HHLY, 5 rue de la Doua, CS 70077, 69626 Villeurbanne CEDEX, France \\ ${ }^{4}$ US Geological Survey, Alaska Cooperative Fish and Wildlife Research Unit, University of Alaska Fairbanks, \\ Fairbanks, AK, USA \\ ${ }^{5}$ National Center for Atmospheric Research, Boulder, CO, USA \\ ${ }^{6}$ Met Office Hadley Centre, FitzRoy Road, Exeter EX1 3PB, UK \\ ${ }^{7}$ Department of Civil and Environmental Engineering, University of Washington, Seattle, WA, USA \\ ${ }^{8}$ CNRM-GAME, Unitémixte de recherche CNRS/Meteo-France (UMR 3589), 42 avCoriolis, \\ 31057 Toulouse CEDEX, France \\ ${ }^{9}$ Lawrence Berkeley National Laboratory, Berkeley, CA, USA \\ ${ }^{10} \mathrm{School}$ of Earth and Ocean Sciences, University of Victoria, Victoria, BC, Canada \\ ${ }^{11}$ College of Global Change and Earth System Science, Beijing Normal University, Beijing, China \\ ${ }^{12}$ Alfred Wegener Institute Helmholtz Centre for Polar and Marine Research, Potsdam, Germany \\ ${ }^{13}$ Research Institute for Global Change, Japan Agency for Marine-Earth Science and Technology, \\ Yokohama, Kanagawa, Japan \\ ${ }^{14}$ Department of Physical Geography and Ecosystem Science, Lund University, Sölvegatan 12, 22362 Lund, Sweden \\ ${ }^{15}$ School of Earth and Space Exploration, Arizona State University, Tempe, AZ, USA \\ ${ }^{16}$ National Institute of Polar Research, Tachikawa, Tokyo, Japan \\ Correspondence to: S. Peng (shushi.peng@1sce.ipsl.fr)
}

Received: 19 January 2015 - Published in The Cryosphere Discuss.: 9 April 2015

Revised: 22 November 2015 - Accepted: 5 December 2015 - Published: 20 January 2016

\begin{abstract}
Soil temperature $\left(T_{\mathrm{S}}\right)$ change is a key indicator of the dynamics of permafrost. On seasonal and interannual timescales, the variability of $T_{\mathrm{s}}$ determines the activelayer depth, which regulates hydrological soil properties and biogeochemical processes. On the multi-decadal scale, increasing $T_{\mathrm{s}}$ not only drives permafrost thaw/retreat but can also trigger and accelerate the decomposition of soil organic carbon. The magnitude of permafrost carbon feedbacks is thus closely linked to the rate of change of soil thermal regimes. In this study, we used nine process-based ecosystem models with permafrost processes, all forced by different observation-based climate forcing during the period 1960-2000, to characterize the warming rate of $T_{\mathrm{S}}$ in per-
\end{abstract}

mafrost regions. There is a large spread of $T_{\mathrm{s}}$ trends at $20 \mathrm{~cm}$ depth across the models, with trend values ranging from $0.010 \pm 0.003$ to $0.031 \pm 0.005^{\circ} \mathrm{C} \mathrm{yr}^{-1}$. Most models show smaller increase in $T_{\mathrm{s}}$ with increasing depth. Air temperature $\left(T_{\mathrm{a}}\right)$ and longwave downward radiation (LWDR) are the main drivers of $T_{\mathrm{S}}$ trends, but their relative contributions differ amongst the models. Different trends of LWDR used in the forcing of models can explain $61 \%$ of their differences in $T_{\mathrm{s}}$ trends, while trends of $T_{\mathrm{a}}$ only explain $5 \%$ of the differences in $T_{\mathrm{s}}$ trends. Uncertain climate forcing contributes a larger uncertainty in $T_{\mathrm{s}}$ trends $\left(0.021 \pm 0.008^{\circ} \mathrm{C} \mathrm{yr}^{-1}\right.$, mean \pm standard deviation) than the uncertainty of model

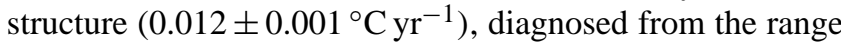


of response between different models, normalized to the same forcing. In addition, the loss rate of near-surface permafrost area, defined as total area where the maximum seasonal active-layer thickness (ALT) is less than $3 \mathrm{~m}$ loss rate, is found to be significantly correlated with the magnitude of the trends of $T_{\mathrm{s}}$ at $1 \mathrm{~m}$ depth across the models $(R=-0.85, P=0.003)$, but not with the initial total nearsurface permafrost area $(R=-0.30, P=0.438)$. The sensitivity of the total boreal near-surface permafrost area to $T_{\mathrm{S}}$ at $1 \mathrm{~m}$ is estimated to be of $-2.80 \pm 0.67$ million $\mathrm{km}^{2}{ }^{\circ} \mathrm{C}^{-1}$. Finally, by using two long-term LWDR data sets and relationships between trends of LWDR and $T_{\mathrm{s}}$ across models, we infer an observation-constrained total boreal near-surface permafrost area decrease comprising between $39 \pm 14 \times 10^{3}$ and $75 \pm 14 \times 10^{3} \mathrm{~km}^{2} \mathrm{yr}^{-1}$ from 1960 to 2000 . This corresponds to $9-18 \%$ degradation of the current permafrost area.

\section{Introduction}

Arctic permafrost regions store $\sim 1300 \mathrm{Pg}$ carbon $(\mathrm{C})$ in the soil, including $\sim 1100 \mathrm{PgC}$ in frozen soil and deposits (Hugelius et al., 2014). Decomposition of these large carbon pools in response to permafrost thawing from projected future warming is expected to be a positive feedback on climate warming through increased emissions of $\mathrm{CO}_{2}$ and $\mathrm{CH}_{4}$ (Khvorostyanov et al., 2008; Schuur et al., 2008; McGuire et al., 2009; Koven et al., 2011; Schaefer et al., 2011). The magnitude of permafrost soil carbon feedbacks on climate depends on the rate of soil carbon decomposition, which is related to permafrost thaw; soil water and temperature changes; the quantity and quality of soil carbon available as a substrate for decomposition; and the concentration of oxygen in the soil, which determines the $\mathrm{CH}_{4}$ vs. $\mathrm{CO}_{2}$ production ratio (Schuur et al., 2008; Schädel et al., 2014; Elberling et al., 2013). Both the rate of permafrost thaw and the rate of soil carbon decomposition are closely related to soil thermal dynamics (Koven et al., 2011; Schädel et al., 2014; Elberling et al., 2013).

Measurements of active-layer depth across circumpolar regions and borehole temperature profiles indicate that activelayer thickness (ALT) on top of boreal permafrost has been increasing in response to the warming that occurred during recent decades in North America, northern Europe, and Russia (e.g., Zhang et al., 2001; Qian et al., 2011; Smith et al., 2005, 2010; Romanovsky et al., 2007, 2010). For example, the borehole record of Alert in Canada $\left(82^{\circ} 30^{\prime} \mathrm{N}, 62^{\circ} 25^{\prime} \mathrm{W}\right)$ shows that soil temperature at 9,15 , and $24 \mathrm{~m}$ increased at rates of $0.6,0.4$, and $0.2{ }^{\circ} \mathrm{C} \mathrm{decade}^{-1}$ from 1978 to 2007 , respectively (Smith et al., 2012). These observations provide long-term local monitoring of changes in active-layer thickness and soil temperature, but the measurement sites are sparse, and their temporal sampling frequency is often low (Romanovsky et al., 2010). Because site measurements can- not document permafrost area loss on a large scale, land surface models including "cold processes", such as soil freezethaw and the thermal and radiative properties of snow, are important tools for quantifying the rate of permafrost degradation on a large scale, and its evolution in response to climate change scenarios.

However, there are large uncertainties in soil thermal dynamics in land surface models (e.g., Koven et al., 2013), and these uncertainties also impact predictions of carboncycle feedbacks on climate. To quantify and reduce the uncertainty of modeled soil temperature $\left(T_{\mathrm{S}}\right)$, the driving factors of $T_{\mathrm{S}}$ trends need to be investigated. Besides the uncertainty in model parameterization and structure, the gridded climate forcing for offline land surface models over highlatitude regions has large uncertainty (e.g., Troy and Wood, 2009; Rawlins et al., 2010). It is also important to distinguish the uncertainty caused by assigned parameter values and model structure from the uncertainty attributable to uncertain climate-forcing data.

In this study, nine process-based models that participated in the Permafrost Carbon Network (PCN, www. permafrostcarbon.org) were used (1) to compare trends of simulated $T_{\mathrm{S}}$ at different depths over the boreal permafrost regions during the past 4 decades and to assess the uncertainty of modeled $T_{\mathrm{S}}$ trends; (2) to identify which factors drive trends of permafrost $T_{\mathrm{s}}$; and (3) to quantify the sensitivity of changes in near-surface permafrost area to warming.

\section{Methods}

\subsection{Models and simulations}

The nine land surface models that were used to simulate $T_{\mathrm{S}}$ in permafrost regions organized by the PCN (www. permafrostcarbon.org) are listed in Table 1. All the models used a finite-difference solution of heat equation with phase change to simulate $T_{\mathrm{s}}$, but models have different soil depths, snow parameterizations, and soil thermal conductivities (Table 1). Three models (CLM, ISBA, UW-VIC) explicitly considered organic soil insulation, and seven models explicitly considered the effect of water in soil on phase change. All models explicitly considered snow insulation but with different snow layers. The soil thermal conductivity depends on soil moisture in all models. More details can be found in Rawlins et al. (2015) and Koven et al. (2015). We defined the Northern Hemisphere permafrost spatial domain as in Fig. 1, and the analysis considers three permafrost regions: boreal North America (BONA), boreal Europe (BOEU), and boreal Asia (BOAS) (Fig. 1; Brown et al., 1998). We did not include the Tibetan Plateau because not all the models covered this region. Hereafter, the term "boreal regions" is used for the sum of the three sub-regions BONA, BOEU, and BOAS in Fig. 1. 
Table 1. Soil depth for soil thermal dynamics and climate forcing used in each model.

\begin{tabular}{|c|c|c|c|c|c|c|}
\hline Model & $\begin{array}{l}\text { Soil depth } \\
\text { (m) }\end{array}$ & $\begin{array}{l}\text { Soil } \\
\text { discretization layers }\end{array}$ & $\begin{array}{l}\text { Bottom } \\
\text { boundary } \\
\text { geothermal } \\
\text { heat flux } \\
\left(\mathrm{mW} \mathrm{m}^{-2}\right)\end{array}$ & $\begin{array}{l}\text { Climate forcing } \\
\text { (reference) }\end{array}$ & Model reference & Note \\
\hline CLM & 45.1 & 30 & 0 & $\begin{array}{l}\text { CRUNCEP v4 } \\
\text { (http://dods.extra.cea. } \\
\text { fr/) }\end{array}$ & Oleson et al. (2013) & \\
\hline CoLM & 3.4 & 10 & 0 & $\begin{array}{l}\text { Princeton } \\
\text { Sheffield et al. (2006) }\end{array}$ & $\begin{array}{l}\text { Dai et al. }(2003,2004) \text {; } \\
\text { Ji et al. (2014) }\end{array}$ & \\
\hline ISBA & 12.0 & 14 & 0 & $\begin{array}{l}\text { WATCH (1901-1978) } \\
\text { WFDEI (1978-2009) } \\
\text { Weedon et al. (2011, } \\
\text { 2014) }\end{array}$ & $\begin{array}{l}\text { Decharme et al. (2011, } \\
\text { 2013) }\end{array}$ & \\
\hline JULES & 20.8 & 16 & 0 & $\begin{array}{l}\text { WATCH (1901-2001) } \\
\text { Weedon et al. (2011) }\end{array}$ & $\begin{array}{l}\text { Best et al. (2011); Clark } \\
\text { et al. (2011) }\end{array}$ & \\
\hline $\begin{array}{l}\text { LPJ- } \\
\text { GUESS }\end{array}$ & 3.0 & 8 & 0 & $\begin{array}{l}\text { CRU TS } 3.1 \\
\text { Harris et al. (2014) }\end{array}$ & $\begin{array}{l}\text { Smith et al. (2001); } \\
\text { McGuire et al. (2012) }\end{array}$ & $\begin{array}{l}\text { Soil temperature in the top } 3 \mathrm{~m} \\
\text { is based on another six padding } \\
\text { layers }(10 \mathrm{~m}) \text { below as the bot- } \\
\text { tom layer condition. Surface } \\
\text { shortwave downward radiation } \\
\text { was calculated from cloudiness } \\
\text { data set; no longwave down- } \\
\text { ward radiation or vapor pres- } \\
\text { sure was used. }\end{array}$ \\
\hline $\begin{array}{l}\text { MIROC- } \\
\text { ESM }\end{array}$ & 14.0 & 6 & 0 & $\begin{array}{l}\text { CMIP5 Drivers } \\
\text { Watanabe et al. (2011) }\end{array}$ & Watanabe et al. (2011) & \\
\hline ORCHIDEE & 47.4 & 32 & 58 & $\begin{array}{l}\text { WATCH (1901-1978) } \\
\text { WFDEI (1978-2009) } \\
\text { Weedon et al. (2011, } \\
\text { 2014) }\end{array}$ & $\begin{array}{l}\text { Krinner et al. (2005); } \\
\text { Koven et al. (2011); } \\
\text { Gouttevin et al. (2012) }\end{array}$ & \\
\hline UVic & 250.3 & 14 & 0 & $\begin{array}{l}\text { CRUNCEP v4 } \\
\text { (http://dods.extra.cea. } \\
\text { fr/) }\end{array}$ & $\begin{array}{l}\text { Avis et al. (2011), } \\
\text { MacDougall et } \\
\text { al. (2012) }\end{array}$ & $\begin{array}{l}\text { Surface shortwave and long- } \\
\text { wave downward radiation were } \\
\text { internally calculated. }\end{array}$ \\
\hline UW-VIC & 25.0 & 25 & 0 & $\begin{array}{l}\text { temperature from CRU } \\
\text { TS3.1, precipitation } \\
\text { from UDel, wind speed } \\
\text { from NCEP-NCAR } \\
\text { Mitchell and } \\
\text { Jones (2005); Willmott } \\
\text { and Matsura (2001); } \\
\text { Adam et al. (2006); } \\
\text { Kalnay et al. (1996) }\end{array}$ & Bohn et al. (2013) & $\begin{array}{l}\text { Surface shortwave and long- } \\
\text { wave downward radiation were } \\
\text { internally calculated. }\end{array}$ \\
\hline
\end{tabular}

Following the simulation protocol of the PCN project, nine land surface models performed historical simulations from 1960 to 2000, using different forcing data sets (Table 1). The different modeling groups in this study used different forcing data sets for climate and other model boundary conditions (Table 1), which collectively represent uncertainty both from climate forcing (and other forcing files) and from model parameterization and structure in simulating soil thermal dynamics across the permafrost region. Climate-forcing data chosen by each group are presented in Table 1 , and the differences in the trend of $T_{\mathrm{a}}$, precipitation, and radiative forcing are summarized in Figs. S1 and S2 in the Supplement. How differences between these drivers are related to differences of the modeled $T_{\mathrm{S}}$ is discussed in the Results and discussion section.
To separate the contributions of the trends of four forcing variables $\left(T_{\mathrm{a}}\right.$, atmospheric $\mathrm{CO}_{2}$, precipitation, and longwave downward radiation (LWDR)) to permafrost thermal dynamics and carbon stocks, six out of the nine models conducted factorial simulations (R01-R04). The ORCHIDEE and JULES performed two additional simulations (R05R06) to isolate the contribution of LWDR to $T_{\mathrm{S}}$ trends (Tables 2 and 3). In the reference simulation R01, all drivers varied at the same time. In R02 $T_{\mathrm{a}}$ was detrended; in R03 atmospheric $\mathrm{CO}_{2}$ was set constant to the observed 1960 level of 316 ppmv; in R04 both $T_{\mathrm{a}}$ and precipitation were detrended; in R05 $T_{\mathrm{a}}$ and LWDR were detrended; and in R06 $T_{\mathrm{a}}$, precipitation, and LWDR were detrended. Differences between two simulations were used to separate the controlling effect of each driver on $T_{\mathrm{s}}$. The interactions between $\mathrm{CO}_{2}$ and $T_{\mathrm{a}}$ as well as precipitation are also included in the differences 
Table 2. Description of simulations used in this study.

\begin{tabular}{lll}
\hline Simulation ID & Climate & $\mathrm{CO}_{2}$ \\
\hline R01 & variable & variable \\
R02 & variable, but with detrended $T_{\mathrm{a}}$ & variable \\
R03 & variable & constant in the year of 1960 \\
R04 & variable, but with detrended $T_{\mathrm{a}}$ and precipitation & variable \\
R05 & variable, but with detrended $T_{\mathrm{a}}$ and LWDR & variable \\
R06 & variable, but with detrended $T_{\mathrm{a}}$, precipitation, and LWDR & variable \\
\hline
\end{tabular}

Table 3. The trends of annual air temperature $\left(T_{\mathrm{a}}\right)$, precipitation, and longwave downward radiation (LWDR) in the second to fourth columns. The fifth column shows the trends of annual $T_{\mathrm{S}}$ at $20 \mathrm{~cm}$ in the reference simulation (R01). The last four columns show the contributions of drivers $\left(T_{\mathrm{a}}\right.$, precipitation, $\mathrm{CO}_{2}$, and LWDR) to the trend of $T_{\mathrm{S}}$ as mentioned in the Methods section. The relative contributions (divided by the trend of $T_{\mathrm{S}}$ in Ref) are shown in the parentheses. The bold font indicates statistical significance $(P<0.05)$.

\begin{tabular}{|c|c|c|c|c|c|c|c|c|}
\hline Model & $\begin{array}{l}\text { Trend of } T_{\mathrm{a}} \\
\left({ }^{\circ} \mathrm{Cyr}^{-1}\right)\end{array}$ & $\begin{array}{l}\text { Trend of } \\
\text { precipitation } \\
\left(\mathrm{mmyr}^{-2}\right)\end{array}$ & $\begin{array}{l}\text { Trend of } \\
\text { LWDR } \\
\left(\mathrm{W} \mathrm{m}^{-2} \mathrm{yr}^{-1}\right)\end{array}$ & $\begin{array}{l}\text { Simulated } \\
\text { trend of } \\
T_{\mathrm{S}}(\mathrm{R} 01) \\
\left({ }^{\circ} \mathrm{Cyr}-1\right)\end{array}$ & $\begin{array}{l}\text { Contribution } \\
\text { from } T_{\mathrm{a}} \\
(\mathrm{R} 01-\mathrm{R} 02) \\
\left({ }^{\circ} \mathrm{Cyr}^{-1}\right)\end{array}$ & $\begin{array}{l}\text { Contribution } \\
\text { from precipitation } \\
(\mathrm{R} 02-\mathrm{R} 04) \\
\left({ }^{\circ} \mathrm{Cyr}^{-1}\right)\end{array}$ & $\begin{array}{l}\text { Contribution } \\
\text { from } \mathrm{CO}_{2} \\
(\mathrm{R} 01-\mathrm{R} 03) \\
\left({ }^{\circ} \mathrm{Cyr}^{-1}\right)\end{array}$ & $\begin{array}{l}\text { Contribution } \\
\text { from LWDR } \\
(\mathrm{R} 02-\mathrm{R} 05) \\
\left({ }^{\circ} \mathrm{Cyr}^{-1}\right)\end{array}$ \\
\hline CLM & 0.031 & 0.13 & 0.114 & $0.016(100 \%)$ & $0.015(92 \%)$ & $-0.002(-12 \%)$ & $0.001(4 \%)$ & - \\
\hline CoLM & 0.031 & -0.05 & 0.058 & $0.010(100 \%)$ & - & - & - & - \\
\hline ISBA & 0.033 & -0.17 & 0.183 & $0.030(100 \%)$ & $0.030(99 \%)$ & $0.001(2 \%)$ & $0.000(-1 \%)$ & - \\
\hline JULES & 0.034 & 0.31 & 0.189 & $0.017(100 \%)$ & $-0.001(-6 \%)$ & $-0.005(-28 \%)$ & $0.000(0 \%)$ & $0.005(31 \%)$ \\
\hline LPJ-GUESS & 0.033 & 0.11 & & $0.026(100 \%)$ & $0.018(67 \%)$ & $0.000(-1 \%)$ & $-0.001(-5 \%)$ & - \\
\hline MIROC-ESM & 0.025 & 0.44 & 0.140 & $0.024(100 \%)$ & - & - & - & - \\
\hline ORCHIDEE & 0.045 & 0.00 & 0.201 & $0.030(100 \%)$ & $0.010(34 \%)$ & $0.002(7 \%)$ & $0.001(2 \%)$ & $0.017(56 \%)$ \\
\hline UVic & 0.031 & 0.11 & & $0.031(100 \%)$ & $0.017(56 \%)$ & $0.000(0 \%)$ & $0.000(-1 \%)$ & - \\
\hline UW-VIC & 0.031 & 2.01 & 0.125 & $0.011(100 \%)$ & $0.029(266 \%)$ & $-0.005(-47 \%)$ & $0.000(0 \%)$ & - \\
\hline
\end{tabular}

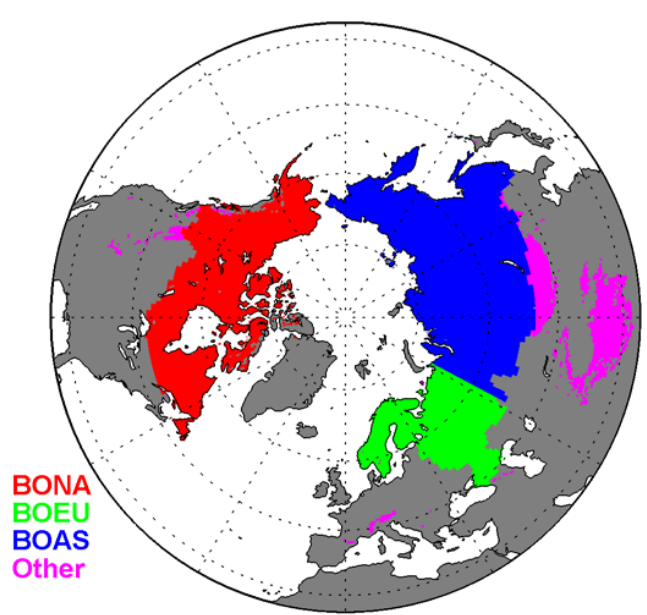

Figure 1. The spatial extent of regions defined in this study. Red, green, blue, and magenta indicate the regions of boreal North America (BONA), boreal Europe (BOEU), boreal Asia (BOAS), and other permafrost areas (Other), respectively. We only selected the BONA, BOEU, and BOAS sub-regions for analysis in this study.

between the two simulations. For example, enhanced vegetation growth by increased $T_{\mathrm{a}}$ /precipitation may transpire less water under higher $\mathrm{CO} 2$ conditions.

\subsection{Analysis}

Modeled monthly $T_{\mathrm{s}}$ at $5,20,50,100,200$, and $300 \mathrm{~cm}$ depths in every grid cell of each model was calculated by linear interpolation of $T_{\mathrm{S}}$ between the central depths of two adjacent layers. Modeled $T_{\mathrm{S}}$ at depths deeper than $300 \mathrm{~cm}$ (six models modeled Ts deeper than $300 \mathrm{~cm}$, except CoLM, JULES and LPJ-GUESS was not extrapolated (the maximum soil depth of each model is shown in Table 1). For each of the boreal sub-regions - BONA, BOEU, and BOAS (Fig. 1) $-T_{\mathrm{S}}$ was first averaged over all grid cells and the trend of regional mean $T_{\mathrm{s}}$ (denoted $\dot{T}_{\mathrm{s}}$ ) was calculated from a linear regression. The statistical significance of $\dot{T}_{\mathrm{S}}$ is evaluated by a $t$ test.

To estimate the uncertainty of $\dot{T}_{\mathrm{S}}$ caused by differences in the trend of each climate input variable, we regressed $\dot{T}_{\mathrm{s}}$ against the trends of $T_{\mathrm{a}}$, precipitation, shortwave downward radiation (SWDR), and LWDR using the output of R01. The uncertainty of $\dot{T}_{\mathrm{S}}$ attributed to each forcing variable was defined as the resulting range of $\dot{T}_{\mathrm{s}}$ associated with different trends in each forcing variable in the models. To achieve this aim, we regressed $\dot{T}_{\mathrm{S}}$ against forcing variable across the models, and the uncertainty of $\dot{T}_{\mathrm{s}}$ resulting from uncertain forcing data was calculated as the range of $\dot{T}_{\mathrm{s}}$ from the maximum and minimum values of forcing data in the regression equation. Then we define the $\dot{T}_{\mathrm{s}}$ uncertainty attributed to model structure, which reflects the differences in model parameteriza- 
tions and parameter values, as the uncertainty of $\dot{T}_{\mathrm{s}}$ assuming all models were using the same climate-forcing data.

Here, we defined near-surface permafrost as in previous studies (e.g., Schneider von Deimling et al., 2012): nearsurface permafrost is defined as where the maximum seasonal thaw depth (i.e., ALT) is less than $3 \mathrm{~m}$. The total nearsurface permafrost area (NSPA) is the sum of the areas of grid cells that fulfill this condition.

We used monthly LWDR data from CRUNCEP v5.2 (http://dods.extra.cea.fr/data/p529viov/cruncep) and WATCH (Weedon et al., 2011) with a spatial resolution of $0.5^{\circ}$ by $0.5^{\circ}$ during the period $1960-2000$ to derive the trend of LWDR. The CRUNCEP LWDR data set was derived from CRU TS3.21 and NCEP reanalysis meteorology, and ancillary data sets (e.g., Wei et al., 2014). The WATCH LWDR data set was derived from ERA-40 reanalysis (Weedon et al., 2011). Because there is no long-term, large-scale LWDR observation product available, we did an experiment using LWDR from CRUNCEP and WATCH data to estimate the loss of permafrost area during the period 1960-2000 by an empirical relationship between the loss of permafrost area and LWDR trends in seven out of the nine models (except LPJ-GUESS and UVic because LWDR was not used by these two models) (see Sect. 3.4 below).

\section{Results and discussion}

\subsection{Trend in upper-layer soil temperature over boreal regions}

The simulated values of $\dot{T}_{\mathrm{s}}$ at $20 \mathrm{~cm}$ depth averaged over boreal regions range from $0.010 \pm 0.003{ }^{\circ} \mathrm{C} \mathrm{yr}^{-1}(\mathrm{CoLM})$ to $0.031 \pm 0.005^{\circ} \mathrm{C} \mathrm{yr}^{-1}$ (UVic) during the period $1960-2000$ (Fig. 2). Figure 3 shows $\dot{T}_{\mathrm{s}}$ at $20 \mathrm{~cm}$ for BONA, BOEU, and BOAS regions. Six out of the nine models show the largest $\dot{T}_{\mathrm{S}}$ at $20 \mathrm{~cm}$ in BOAS, followed by BONA and BOEU. The other three models (CoLM, JULES, and UW-VIC) show the smallest $\dot{T}_{\mathrm{s}}$ at $20 \mathrm{~cm}$ in BOAS. Among the six models with smaller $\dot{T}_{\mathrm{S}}$ at $20 \mathrm{~cm}$ in BOEU, we found that $\dot{T}_{\mathrm{S}}$ at $20 \mathrm{~cm}$ in BOEU is significantly lower than in BOAS and in BONA $(P<0.001$, two-sample $t$ test). This is also shown in the spatial distribution of $\dot{T}_{\mathrm{s}}$ at $20 \mathrm{~cm}$ (Fig. 4). For example, in northern Siberia, $T_{\mathrm{S}}$ at $20 \mathrm{~cm}$ increased by more than $0.02{ }^{\circ} \mathrm{Cyr}^{-1}$ in five out of the nine models (ISBA, LPJ-GUESS, MICRO-ESM, ORCHIDEE, and UVic) but decreased in two models (CoLM and JULES). All models show an increase of $T_{\mathrm{S}}$ at $20 \mathrm{~cm}$ in northern BONA, but this increase is of different magnitude between models (Fig. 4). Six models show significant $\dot{T}_{\mathrm{S}}$ at $20 \mathrm{~cm}$ over northern and western Siberia, but all models show non-significant $\dot{T}_{\mathrm{s}}$ at $20 \mathrm{~cm}$ over northern BOEU (Fig. 4).

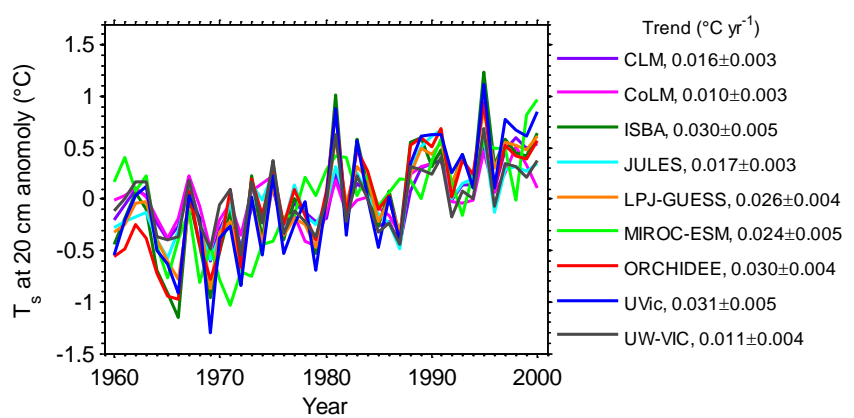

Figure 2. Simulated anomaly of annual $T_{\mathrm{S}}$ at $20 \mathrm{~cm}$ averaged over boreal regions of each model, during the period of 1960-2000.

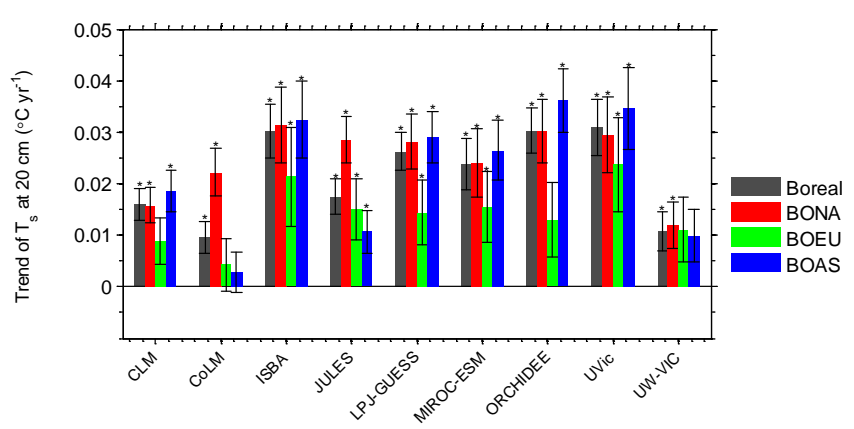

Figure 3. Simulated trends of annual $T_{\mathrm{S}}$ at $20 \mathrm{~cm}$ averaged over boreal regions and sub-regions of each model, from 1960 to 2000. * indicates significant trend of $T_{\mathrm{S}}(P<0.05)$.

\subsection{Attenuation of the trend in soil temperature with soil depth}

The trend of $T_{\mathrm{S}}$ at different soil depths is shown in Fig. 5 for each model. Based on ground soil temperature observation, annual $T_{\mathrm{s}}$ at $1.6 \mathrm{~m}$ increased by $0.02-0.03^{\circ} \mathrm{C} \mathrm{yr}^{-1}$ from the 1960s to 2000s in Russia (Park et al., 2014). The simulated trends of $T_{\mathrm{S}}$ at $1.6 \mathrm{~m}$ over BOAS in most models are within this range (Fig. S3). Two models (CoLM and JULES) show vertically quasi-uniform $\dot{T}_{\mathrm{S}}$ over the upper $3 \mathrm{~m}$ of soil, probably because of too-quick soil thermal equilibrium in these two models. The seven other models show decreasing values of $\dot{T}_{\mathrm{s}}$ with increasing soil depth, but the vertical gradient of $\dot{T}_{\mathrm{S}}$ varies among them (Fig. 5a). UW-VIC has the largest negative vertical gradient of $\dot{T}_{\mathrm{s}}\left(-0.0052 \pm 0.0001^{\circ} \mathrm{C} \mathrm{yr}^{-1} \mathrm{~m}^{-1}\right)$, followed by ISBA, MICRO-ESM, ORCHIDEE, and UVic $\left(\sim-0.0030 \pm 0.0003{ }^{\circ} \mathrm{C} \mathrm{yr}^{-1} \mathrm{~m}^{-1}\right)$ and by near-zero vertical gradient of $\dot{T}_{\mathrm{s}}$ in CLM $\left(-0.0009 \pm 0.0003^{\circ} \mathrm{C} \mathrm{yr}^{-1} \mathrm{~m}^{-1}\right)$ and in LPJ-GUESS $\left(-0.0014 \pm 0.0000^{\circ} \mathrm{C} \mathrm{yr}^{-1} \mathrm{~m}^{-1}\right)$.

Figure $5 \mathrm{~b}$ shows the trend of $T_{\mathrm{S}}$ in all soil layers over boreal regions. CLM and UVic show an increase of $T_{\mathrm{s}}$ even at depths deeper than $40 \mathrm{~m}$, but $T_{\mathrm{S}}$ exhibited no changes deeper than $22 \mathrm{~m}$ in ORCHIDEE (Fig. 5b). $T_{\mathrm{s}}$ increased in the deepest layer of ISBA (12 m) and MIROC-ESM (14 m), and the depth at which $T_{\mathrm{S}}$ exhibited no changes could not be deduced 
(a) CLM

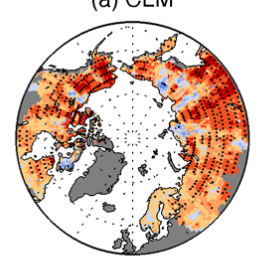

(d) JULES

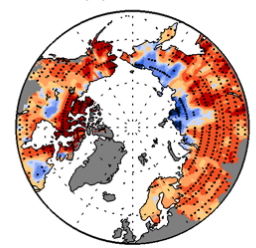

(g) ORCHIDEE

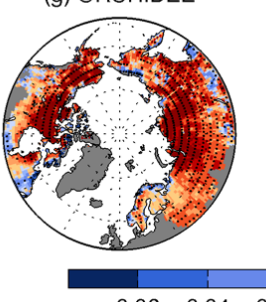

$\begin{array}{lllll}-0.06 & -0.04 & -0.02 & -0.01\end{array}$ (b) CoLM

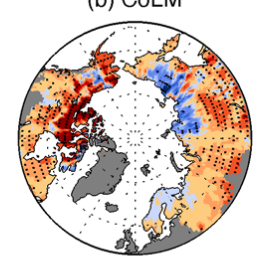

(e) LPJ-GUESS

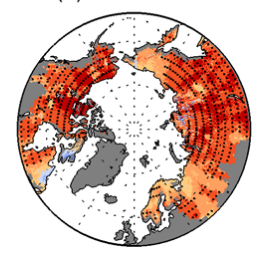

(h) UVic

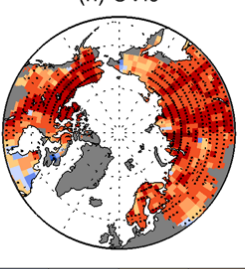

(c) ISBA

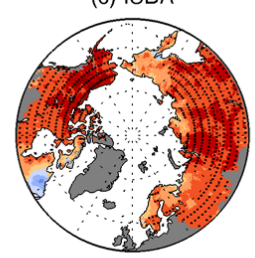

(f) MIROC-ESM

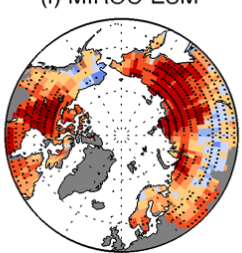

(i) UW-VIC
Figure 4. Spatial distributions of trends of annual $T_{\mathrm{S}}$ at $20 \mathrm{~cm}$ over boreal regions from 1960 to 2000 in (a) CLM, (b) CoLM, (c) ISBA, (d) JULES, (e) LPJ-GUESS, (f) MICRO-ESM, (g) ORCHIDEE, (h) UVic, and (i) UW-VIC models. The black dots indicate regions with significant trends of $T_{\mathrm{S}}(P<0.05)$. Note that extreme values outside of the range of -0.06 to $0.06^{\circ} \mathrm{C} \mathrm{yr}^{-1}$ are shown in the deepest blue and red in the color bar.

from these two models. UW-VIC shows a negative trend of $T_{\mathrm{s}}$ (i.e., cooling) at depths deeper than $2.5 \mathrm{~m}$, which may be related to higher soil heat capacities with increased soil moisture, resulting in cooler summertime soil temperatures and shallower active layers in the regions (Koven et al., 2015). The trends of $T_{\mathrm{S}}$ over BONA, BOEU, and BOAS regions decrease in magnitude with increasing soil depth, but they show different vertical gradients. In Fig. S3, the vertical gradient of $\dot{T}_{\mathrm{S}}$ is shown to be larger in BONA and BOAS than that in BOEU for most models. Figure 6 shows the spatial distribution of the difference in $\dot{T}_{\mathrm{S}}$ at depths between 0.2 and $3 \mathrm{~m} . \dot{T}_{\mathrm{S}}$ at $0.2 \mathrm{~m}$ is larger than that at $3 \mathrm{~m}$ over most regions in BONA, BOEU, and BOAS in seven out of the nine models, except JULES and CoLM. Generally, borehole records show that mean annual soil temperature at depths between 10 and $30 \mathrm{~m}$ has increased during the last 3 decades over the circumpolar northern permafrost regions (Osterkamp, 2003, 2007; Romanovsky et al., 2010; Smith et al., 2005, 2012; Vaughan et al., 2013). In Alaska, $T_{\mathrm{S}}$ at $20 \mathrm{~m}$ from boreholes increased by $\sim 1{ }^{\circ} \mathrm{C}$ between the early 1980 s and 2001 (Osterkamp, 2003). The observed value of $\dot{T}_{\mathrm{S}}$ at one of the Alert (BH3) boreholes is $\sim 0.04^{\circ} \mathrm{C} \mathrm{yr}^{-1}$ at $\sim 2.5 \mathrm{~m}$ depth and nearly zero at $\sim 27 \mathrm{~m}$ depth during the period 1979-2004 (see Fig. 9 in
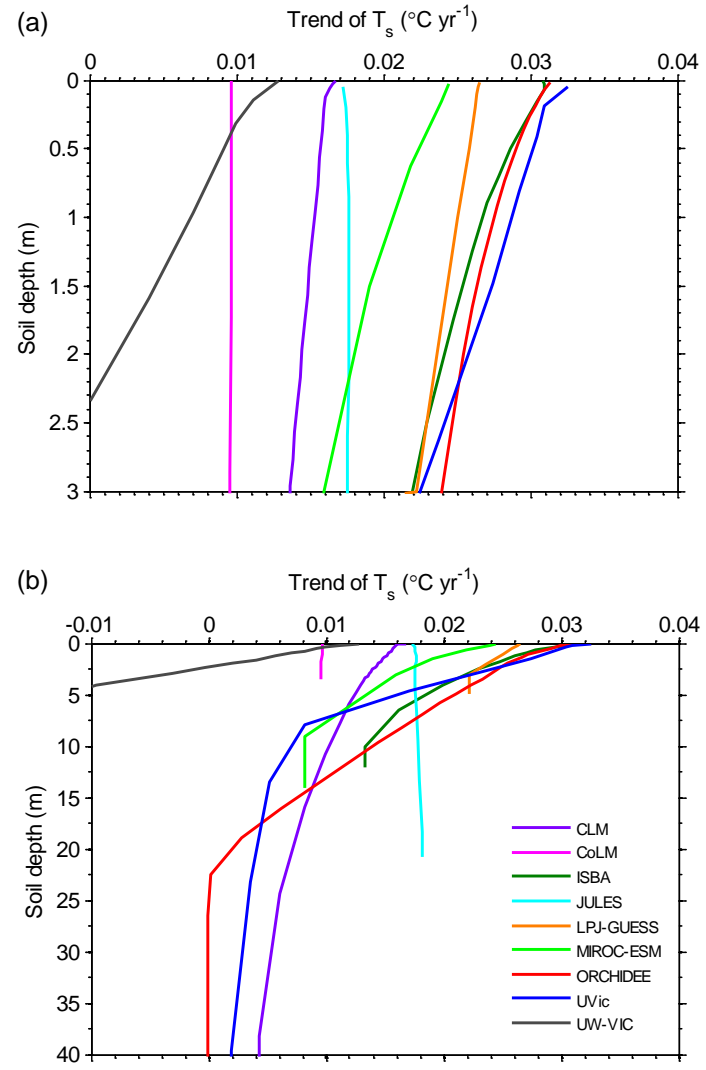

Figure 5. Simulated trends of annual $T_{\mathrm{S}}$ over boreal regions as a function of soil depths (a) 0-3 m and (b) 0-40 $\mathrm{m}$ for the nine models. Note that the different total soil depths of the models and negative trends for UW-VIC $\left(\sim-0.01-0.03{ }^{\circ} \mathrm{C} \mathrm{yr}^{-1}\right)$ below $2.3 \mathrm{~m}$ are not shown in the plots.

Smith et al., 2012). Some boreholes (BH1 and BH2) at Alert, however, still indicated a small warming during the period 1979-2008 (Smith et al., 2012) at $37 \mathrm{~m}$. This suggests that much deeper maximum soil depth than the currently prescribed maximum soil depths (Table 1) is needed for some models to calculate the heat flux into the entire soil profile (Stevens et al., 2007). CoLM, JULES, and LPJ-GUESS have too shallow a maximum soil depth for the calculation of permafrost soil temperature trends over the last 4 decades, which makes these models even less realistic for deeper $T_{\mathrm{S}}$ projections over the next century (e.g., Alexeev et al., 2007). Compared to the increased ground temperature at depths deeper than $20 \mathrm{~m}$ in boreholes during the past 3 decades (Vaughan et al., 2013), most models that do not have deeper soil depth seem to underestimate the penetration of heat into deep soil layers (Fig. 5b). For the bottom boundary geothermal heat flux, eight out of the nine models are assumed to be zero. The ignored boundary geothermal heat flux is valid for the upper $20-30 \mathrm{~m}$ of soil within century scale (Nicolsky et al., 2007), but for millennial or longer glacial-interglacial-cycle permafrost simulation, the bottom boundary geothermal heat 

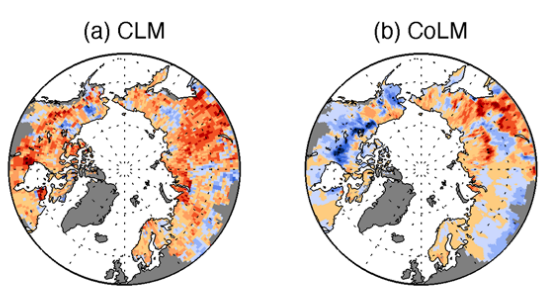

(e) LPJ-GUESS
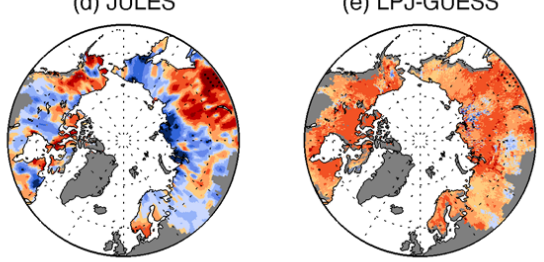

(h) UVic
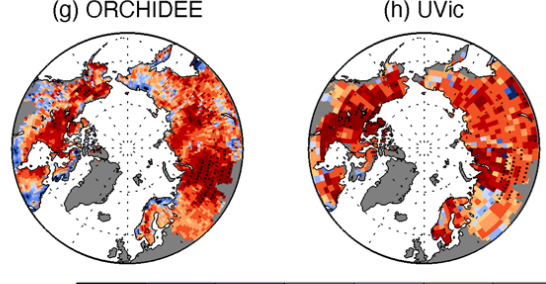

$-0.015-0.01-0.005-0.002$

0

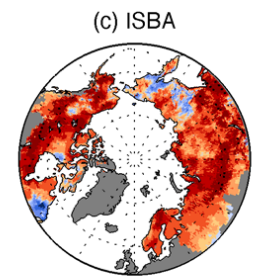

(f) MIROC-ESM

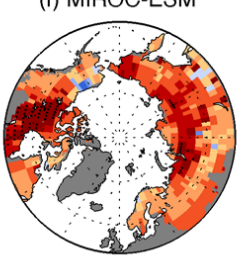

(i) UW-VIC

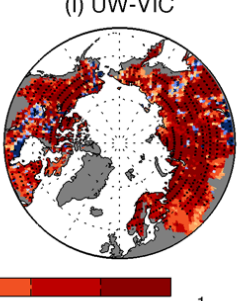

Figure 6. Spatial distributions of difference in trends of annual $T_{\mathrm{S}}$ at 0.2 and $3 \mathrm{~m}$ over boreal regions from 1960 to 2000 in (a) CLM, (b) CoLM, (c) ISBA, (d) JULES, (e) LPJ-GUESS, (f) MICROESM, (g) ORCHIDEE, (h) UVic, and (i) UW-VIC models. The black dots indicate statistically significant difference by $t$ test $(P<0.05)$. Note that extreme values outside of the range of -0.015 to $0.015^{\circ} \mathrm{C} \mathrm{yr}^{-1}$ are shown in the deepest blue and red in the color bar.

flux should not be ignored. Note that this comparison may be biased because of different periods and climate records between sites and model grid cells. It is also recommended that simulations at site level using in situ local climate forcing be compared with temperature profiles of boreholes (Smith et al., 2012) to evaluate why models underestimate the warming of $T_{\mathrm{s}}$ at deeper depths.

\subsection{Drivers of trends in soil temperature}

We used the sensitivity runs (R02-R06) compared with the reference simulation with all drivers varying together (R01) to separate the effects of $T_{\mathrm{a}}, \mathrm{CO}_{2}$, precipitation, and LWDR on $\dot{T}_{\mathrm{s}}$ during 1960-2000 (Table 3). Seven of the nine models only provided results from R02, R03, and R04. Except for JULES, all the models show a positive response of $T_{\mathrm{s}}$ to increasing $T_{\mathrm{a}}$, albeit with different sensitivities (Table 3 ). The fraction of the trend of $T_{\mathrm{S}}$ explained by air temperature increase alone (R01-R02) is nearly $100 \%$ in CLM and ISBA, and more than $100 \%$ in UW-VIC, against only 34, 56, and $67 \%$ in ORCHIDEE, UVic, and LPJ-GUESS, respectively. This indicates the importance of increasing $T_{\mathrm{a}}$ for the trend of $T_{\mathrm{s}}$ and is consistent with observations. Based on $30 \mathrm{cli}-$

mate station observations in Canada during the period 1958$2008, T_{\mathrm{s}}$ at $10 \mathrm{~cm}$ significantly and positively correlates with $T_{\mathrm{a}}$ at most sites (>90\%) in spring, but at fewer sites $(<30 \%)$ in winter (Qian et al., 2011). For winter $T_{\mathrm{s}}$, the winter snow depth was found to have significant and positive correlation with $T_{\mathrm{s}}$ in shallow soil layers (e.g., Zhang et al., 2001; Qian et al., 2011). Recent increases in $T_{\mathrm{a}}$ also explain the trend of $T_{\mathrm{s}}$ at $1.6 \mathrm{~m}$ measured at Churapcha metrological station $\left(62.02^{\circ} \mathrm{N}, 132.36^{\circ} \mathrm{E}\right)$, and at $5 \mathrm{~m}$ measured in a borehole at Iqaluit $\left(63.47^{\circ} \mathrm{N}, 68.48^{\circ} \mathrm{W}\right)$ in Canada (Smith et al., 2005; Romanovsky et al., 2007). To some extent, the trend of $T_{\mathrm{a}}$ is a good indicator for the trend of deep permafrost ground temperature with some time lag (Romanovsky et al., 2007). For the modeled $T_{\mathrm{s}}$ in land surface models, the effects of $T_{\mathrm{a}}$ on $T_{\mathrm{s}}$ depend on surface energy balance and ground heat flux into soil; i.e., the extent of coupled $T_{\mathrm{a}}$ on $T_{\mathrm{s}}$ is related to the surface properties such as snow, organic soil horizons, and roughness in the models. The different relative contributions of the trend of $T_{\mathrm{a}}$ to the trend of $T_{\mathrm{s}}$ in these models perhaps mainly result from the different model parameterization and structures, as the trends of $T_{\mathrm{a}}\left(\sim 0.03{ }^{\circ} \mathrm{C} \mathrm{yr}^{-1}\right)$ in the climate forcing do not have a large spread (Fig. 7).

The increase of atmospheric $\mathrm{CO}_{2}$ concentration has almost no effect on the increase of $T_{\mathrm{s}}$ in most models $(-5$ to $+4 \%$ of increase of $T_{\mathrm{s}}$, Table 3). This is expected since $\mathrm{CO}_{2}$ has no direct effect on $T_{\mathrm{s}}$ apart from its impact on climate. The only indirect effect of rising $\mathrm{CO}_{2}$ on $T_{\mathrm{S}}$ trends could result from feedbacks between plant productivity driven by rising $\mathrm{CO}_{2}$, soil carbon changes, and soil thermal properties. For instance, if models include heat production from microbial decomposition of soil organic carbon (Khvorostyanov et al., 2008) or if changes occur in soil organic carbon from the balance of net primary productivity (NPP) input and decomposition, these could impact the soil temperature directly or the profile of soil heat conductivity and capacity. In that case, the expected response is that a $\mathrm{CO}_{2}$-driven increase of productivity will increase soil organic carbon, which will enhance the insulation effect of soil organic carbon in the soil and lower the trend of $T_{\mathrm{S}}$ (Lawrence et al., 2008; Lawrence and Slater, 2008; Koven et al., 2009). Further, complex changes in the surface energy balance from changes in evapotranspiration under higher $\mathrm{CO}_{2}$ concentrations can influence soil moisture content and affect $T_{\mathrm{s}}$ trends (e.g., Field et al., 1995). Most models do not have a feedback between soil organic carbon dynamics and soil thermal properties, and the increase in soil organic carbon due to rising $\mathrm{CO}_{2}$ is relatively small in the models compared to the initial soil organic carbon storage $(<0.1 \%)$. The changes in evapotranspiration because of increasing $\mathrm{CO}_{2}$ are also relatively small $(-3$ to $+1 \%)$. Therefore, the increased $\mathrm{CO}_{2}$ concentration has a very small effect on $\dot{T}_{\text {s }}$ from 1960 to 2000 .

Precipitation shows an increase in BONA and BOEU and a decrease in BOAS in the climate forcing used by most models (Fig. S1b). None of the trends of boreal precipitation are significant $(P>0.05$; except for the UW-VIC and 


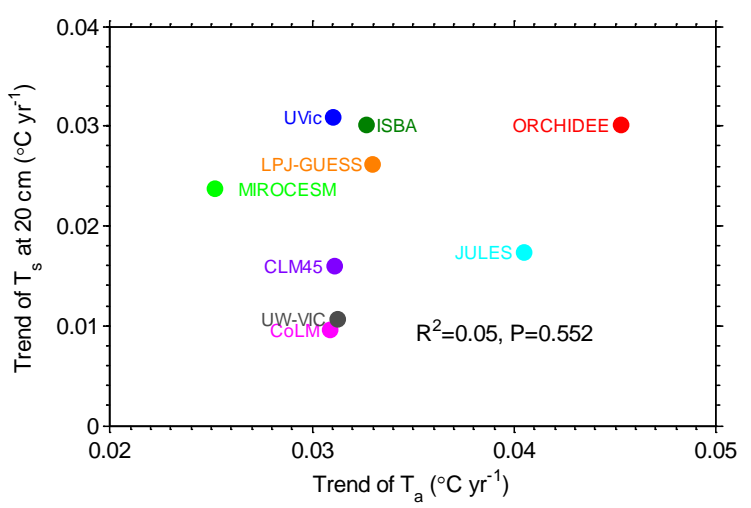

Figure 7. Simulated trends of annual $T_{\mathrm{S}}$ at $20 \mathrm{~cm}$ and $T_{\mathrm{a}}$ in the climate-forcing data across the nine models.

JULES drivers). Changes in precipitation alone (R02-R04) are found to cause a negative trend of $T_{\mathrm{S}}$ in CLM, JULES, and UW-VIC; no effects in LPJ-GUESS and UVic; and a positive trend in ISBA and ORCHIDEE (Table 3). Increasing winter snowfall can enhance $T_{\mathrm{S}}$ in winter through the snow insulation effect (e.g., Smith et al., 2010; Koven et al., 2013). All models in this study indeed show higher winter $T_{\mathrm{S}}$ where winter snow depth became deeper, albeit with different magnitudes of snow insulation effects across the models. The snow insulation effects are smaller in ISBA, LPJGUESS, and UVic than those in the other models. A decrease in snowfall could contribute to a negative trend of $T_{\mathrm{S}}$ in CLM, and an increase in snowfall could enhance $T_{\mathrm{s}}$ in ORCHIDEE (Fig. S4; Table 3). In addition, increased rainfall in summer can cause an increase in evapotranspiration during the growing seasons, which could reduce the increase of $T_{\mathrm{S}}$. The effects of snowfall trends and growing-season precipitation trends may oppose each other as mentioned above. These two contrasting effects cannot be separated in this analysis, because models did not run simulations with seasonally detrended precipitation. But the different effects of seasonal precipitation on $T_{\mathrm{S}}$ should be studied in the future.

LWDR significantly increased after 1960 in all models, albeit with different trends in the forcing data used by each modeling group $\left(0.058 \sim 0.200 \mathrm{~W} \mathrm{~m}^{-2} \mathrm{yr}^{-1}\right)$ (Fig. S2a). LWDR forcing is mainly from two reanalysis data sets (ERA and NCEP) with corrections (e.g., Weedon et al., 2011; http://dods.extra.cea.fr/data/p529viov/cruncep). ORCHIDEE and JULES performed the simulation R05 with detrended LWDR. The results of R02-R05, allowing $\dot{T}_{\mathrm{s}}$ to be attributed to trends of LWDR, indicate that the increase of LWDR explains 56 and $31 \%$ of the trend of $T_{\mathrm{S}}$ since 1960 in ORCHIDEE and JULES, respectively. Increased LWDR provides additional energy to the surface and dominates the atmosphere-to-soil energy flux in winter over boreal regions when shortwave radiation is low. Even in summer, LWDR contributes $\sim 60 \%$ of total downward radiation (SWDR+LWDR) over boreal regions in CRUNCEP. An in- crease of LWDR with time thus increases the surface energy input, which accelerates the warming of $T_{\mathrm{s}}$ in case the extra energy is not dissipated by an increase of sensible and latent heat flux. The contribution of changes in LWDR, $T_{\mathrm{a}}$, and other factors to all components of the surface energy budget and to $T_{\mathrm{S}}$ could be further studied by testing models against observations from eddy-flux towers located in permafrost soils.

\subsection{Uncertainty of modeled soil temperature trends}

The uncertainty of modeled $\dot{T}_{\mathrm{S}}$ at $20 \mathrm{~cm}$ is large, as given by the spread of model results $\left(0.010-0.031^{\circ} \mathrm{C} \mathrm{yr}^{-1}\right)$. The uncertainty of $\dot{T}_{\mathrm{S}}$ across the models can be conceptually decomposed into two components: a forcing uncertainty (FU) reflecting how different climate input data used by each modeling group contribute to the spread of $\dot{T}_{\mathrm{S}}$ (Table 1), and a structural uncertainty (SU) related to uncertain parameter values and different equations and parameterizations of processes in models. Since $T_{\mathrm{a}}$ and LWDR are the two main drivers of the increase of $T_{\mathrm{S}}$ in most of the models (Sect. 3.3), we regressed $\dot{T}_{\mathrm{s}}$ during 1960-2000 against the trends of $T_{\mathrm{a}}$ and LWDR, in order to estimate the FU. We then estimated SU from the uncertainty of parameters in the regression equation for a normalized same climate forcing across the models.

We found no significant correlation between $\dot{T}_{\mathrm{a}}$ and $\dot{T}_{\mathrm{s}}$ over boreal regions or sub-regions across the nine models (Fig. 7 and Fig. S5), indicating that a bias of $\dot{T}_{\mathrm{a}}$ forcing is not simply associated with the bias of $\dot{T}_{\mathrm{s}}$ in a particular model compared to the others. We also found that trends of SWDR and precipitation do not significantly explain differences in $\dot{T}_{\mathrm{s}}$ at $20 \mathrm{~cm}$ across the models $(P>0.05 ; 21$ and $19 \%$ explanation of differences in $\dot{T}_{\mathrm{S}}$ at $20 \mathrm{~cm}$ for trends of SWDR and precipitation, respectively; Fig. S6). The correlations between trends in winter snowfall and trends of annual or winter $T_{\mathrm{s}}$ at $20 \mathrm{~cm}$ are not significant $(P>0.05)$ across the models for boreal regions or sub-regions. However, the trend of LWDR (LWDR) can explain $61 \%$ of the differences in $\dot{T}_{\mathrm{S}}$ at $20 \mathrm{~cm}$ across the models (Fig. 8). This result indicates that, throughout the model ensemble, differences of $\dot{T}_{\mathrm{S}}$ at $20 \mathrm{~cm}$ between models are positively correlated $(R=0.78, P=0.037)$ with differences of LWDR used by the different modeling groups. $\dot{T}_{\mathrm{S}}$ at $1 \mathrm{~m}$ also significantly correlated with LWDR $(R=0.79, P=0.034)$ across the models. The values of LWDR used by different models averaged over permafrost regions range from 0.058 to $0.200 \mathrm{~W} \mathrm{~m}^{-2} \mathrm{yr}^{-1}$, statistically explaining a range of simulated $\dot{T}_{\mathrm{s}}$ at $20 \mathrm{~cm}$ of $0.021 \pm 0.005^{\circ} \mathrm{C} \mathrm{yr}^{-1}$ (solid blue arrow in Fig. 8). This $\dot{T}_{\mathrm{s}}$ range defines the FU (the range of $\dot{T}_{\mathrm{s}}$ to LWDR from 0.058 to $0.200 \mathrm{~W} \mathrm{~m}^{-2} \mathrm{yr}^{-1}$ based on the linear regression of Fig. 8). We also used multiple linear regression between $\dot{T}_{\mathrm{s}}$ at $20 \mathrm{~cm}$ depth and $\dot{T}_{\mathrm{a}}$, with LWDR as the independent variable across the models, to derive an estimation of the $\mathrm{FU}$ in $\dot{T}_{\mathrm{s}}$ of $0.021 \pm 0.008^{\circ} \mathrm{C} \mathrm{yr}^{-1}$ (the deviation was derived from the uncertainty of regression coef- 
(a)

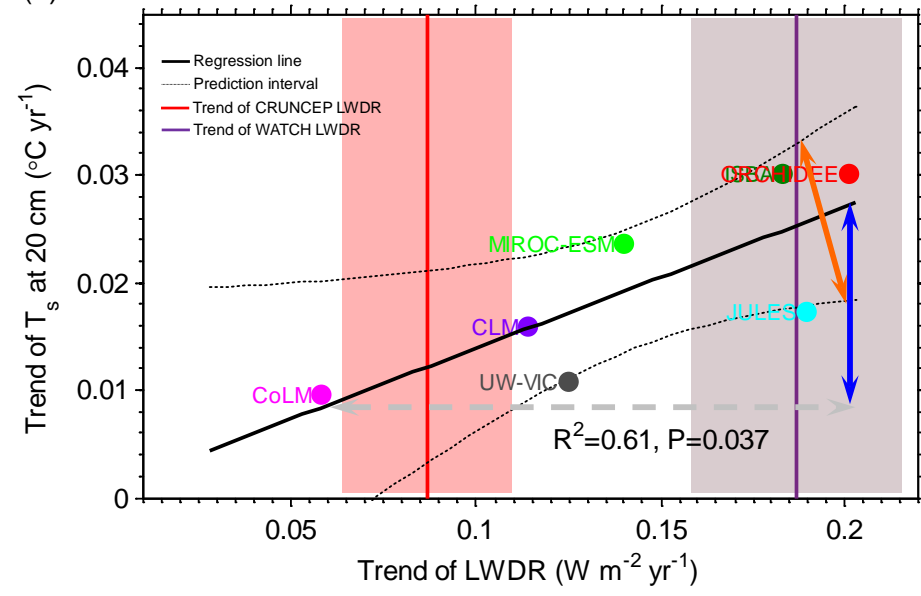

(b)

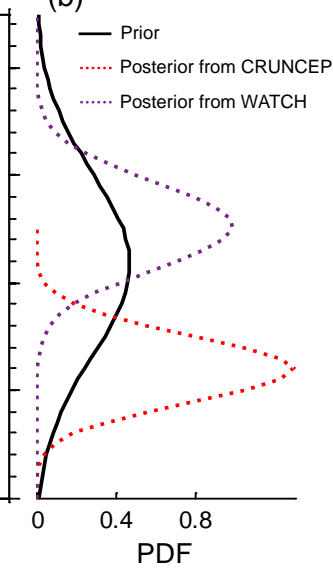

Figure 8. (a) Simulated trends of annual $T_{\mathrm{S}}$ at $20 \mathrm{~cm}$ and annual LWDR in the climate-forcing data over boreal regions across the seven models which used and provided LWDR in their climate forcing. The thin black dotted lines indicate the linear regression and $95 \%$ confidence interval. The gray dashed line with double arrows indicates the uncertainty of the trend of LWDR in the climate-forcing data. The solid blue and orange lines with double arrows indicate FU and SU, respectively. The red solid vertical line with a shaded area shows the trend of LWDR $\left(0.087 \pm 0.023 \mathrm{~W} \mathrm{~m}^{-2} \mathrm{yr}^{-1}\right)$ during the period 1960-2000 from the CRUNCEP v5.2 data set. The purple solid vertical line with a shaded area shows the trend of LWDR $\left(0.187 \pm 0.028 \mathrm{~W} \mathrm{~m}^{-2} \mathrm{yr}^{-1}\right)$ during the period 1960-2000 from the WATCH data set. (b) The prior normal probability density function (PDF) with modeled mean and standard deviation (black solid line) of the trend of $T_{\mathrm{S}}$ at $20 \mathrm{~cm}$ and posterior normal PDF of the trend of annual $T_{\mathrm{S}}$ at $20 \mathrm{~cm}$ with the given trend of LWDR (red dotted line) from CRUNCEP and WATCH (purple dotted line), respectively.

ficients in the multiple linear regression). However, the uncertainty of the linear regression of $\dot{T}_{\mathrm{s}}$ at $20 \mathrm{~cm}$ by LWDR or $\dot{T}_{\mathrm{a}}$ and LWDR shows that, if all the models used the same climate-forcing data, the SU would be $0.012 \pm 0.001^{\circ} \mathrm{C} \mathrm{yr}^{-1}$ (solid orange arrow in Fig. 8). If all models use LWDR from CRUNCEP or WATCH, then, applying the trend of annual LWDR $\left(0.087 \pm 0.023 \mathrm{~W} \mathrm{~m}^{-2} \mathrm{yr}^{-1}\right.$ from CRUNCEP and $0.187 \pm 0.028 \mathrm{~W} \mathrm{~m}^{-2} \mathrm{yr}^{-1}$ from WATCH) during the period 1960-2000 as an emerging observation constraint empirical relationship

in Fig. 8, the posterior range is reduced compared with the prior $\dot{T}_{\mathrm{S}}$ range (black curve in right panel of Fig. 8). Overall, the total uncertainty range of $\dot{T}_{\mathrm{s}}$ at $20 \mathrm{~cm}\left(\sim 0.02^{\circ} \mathrm{C} \mathrm{yr}^{-1}\right.$, defined as the spread of $\dot{T}_{\mathrm{S}}$ at $20 \mathrm{~cm}$ across the models) can be broken down into $\mathrm{FU}\left(0.021 \pm 0.008^{\circ} \mathrm{Cyr}^{-1}\right)$ and $\mathrm{SU}$ $\left(0.012 \pm 0.001{ }^{\circ} \mathrm{C} \mathrm{yr}^{-1}\right)$. Since FU and SU are not independent, the total uncertainty of $\dot{T}_{\mathrm{s}}$ at $20 \mathrm{~cm}$ is not the sum of FU and SU.

Further, we found that correlation coefficients between trends of summer $T_{\mathrm{S}}$ at $20 \mathrm{~cm}$ and at $1 \mathrm{~m}$ and summer LWDR over boreal regions are statistically significant $(P<0.05)$ (Fig. S7). This is also found for winter (November to March) $T_{\mathrm{s}}$ at $20 \mathrm{~cm}$ and $1 \mathrm{~m}$ (Fig. S8). Trends of summer and winter $T_{\mathrm{S}}$ at $20 \mathrm{~cm}$ or $1 \mathrm{~m}$ are not significantly correlated with climate drivers other than LWDR (snowfall, rainfall, $T_{\mathrm{a}}$, and SWDR) across the models $(P>0.05)$.

Meteorological stations are sparse in the cold permafrost regions. For example, there are only 8.8 stations per million square kilometers north of $60^{\circ} \mathrm{N}$ in the CRU TS3.22 gridded air temperature product, compared to 41.1 stations per million square kilometers between 25 and $60^{\circ} \mathrm{N}$. This results in uncertainty in gridded climate products over Arctic regions, especially for trends of Arctic climate variables (Mitchell and Jones, 2005; Troy and Wood, 2009; Rawlins et al., 2010; Weedon et al., 2011). Troy and Wood (2009) reported $15-20 \mathrm{~W} \mathrm{~m}^{-2}$ of differences in radiative fluxes on seasonal timescales over northern Eurasia, among six gridded products. Among different gridded observations and reanalysis precipitation products, the magnitude of Arctic precipitation ranges from 410 to $520 \mathrm{~mm} \mathrm{yr}^{-1}$, and the trend of Arctic precipitation also has a large spread (Rawlins et al., 2010). These large uncertainties in climate forcing in the Arctic undoubtedly can cause a large spread of modeled $T_{\mathrm{S}}$. We found that the FU dominates the total uncertainty of $\dot{T}_{\mathrm{S}}$. This suggests that modelers not only need to improve their models, but they also need better climate-forcing data (or need to test the effects of different climate input data) when modeling long-term changes of $T_{\mathrm{s}}$ in permafrost regions. However, to quantify the SU, simulations using the same agreed-upon climate-forcing data are highly recommended to further attribute the contribution of each process in the soil thermal dynamics of models such as organic carbon insulation effects, snow insulation effects, latent heat formation and emission, soil conductivity, and surface properties (see Lawrence and Slater, 2008; Koven et al., 2009; Bonfils et al., 2012; Gouttevin et al., 2012). In addition, important processes in permafrost regions such as dynamics of excessive ground ice (e.g., ice wedge growth and degradation) and thermokarst 

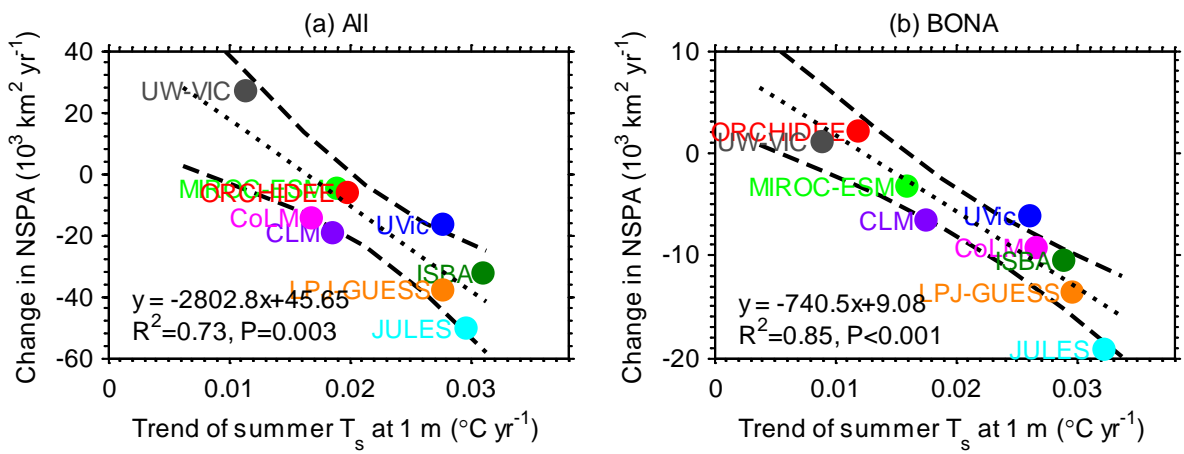

(c) BOEU
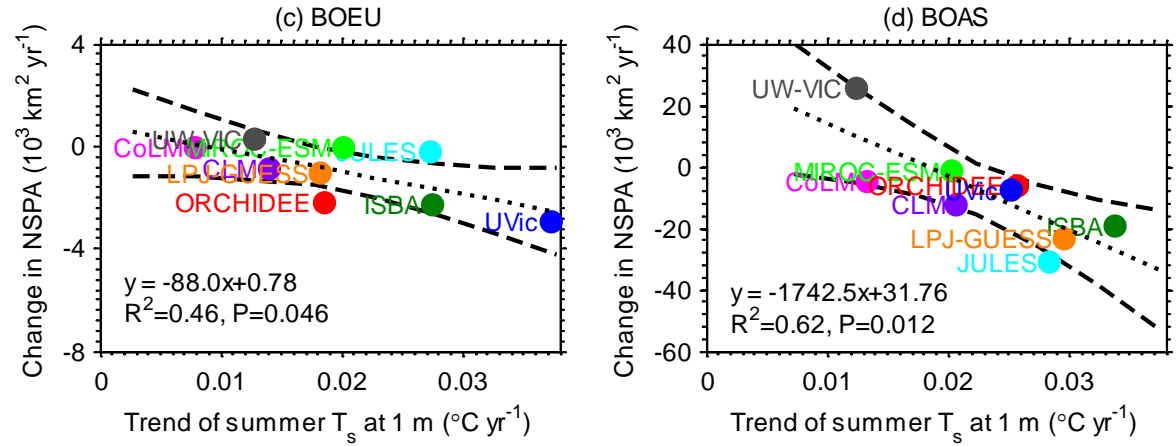

Figure 9. Simulated trends of summer $T_{\mathrm{S}}$ at $1 \mathrm{~m}$ and loss rate of NSPA over (a) boreal regions, (b) BONA, (c) BOEU, and (d) BOAS across the nine models.

lakes (formation, expansion, and drainage) should be developed and evaluated in land surface models to improve the prediction of future permafrost feedbacks (e.g., van Huissteden et al., 2013; Lee et al., 2014).

\subsection{Emerging constraint on how much near-surface permafrost has disappeared}

The total boreal NSPA during 1960-2000 estimated by the nine models ranges from 6.8 million $\mathrm{km}^{2}$ (CoLM) to 19.7 million $\mathrm{km}^{2}$ (ORCHIDEE). The average of total NSPA in the nine-model ensemble $\left(12.5\right.$ million $\left.\mathrm{km}^{2}\right)$ is smaller than the estimate from the International Permafrost Association (IPA) map (16.2 million $\mathrm{km}^{2}$; Brown et al, 1998; Slater and Lawrence et al., 2013). A statistic model based on relationships between air temperature and permafrost shows that permafrost extent over the Northern Hemisphere was also estimated in the range 12.9-17.8 million $\mathrm{km}^{2}$ (Gruber, 2012), and six out of the nine models are within this range. Eight out of the nine models show a significant decrease in NSPA with climate warming during 1960-2000 (except UW-VIC). The loss rate of NSPA is found to vary by a factor of 13 across the nine models, varying from $-4 \times 10^{3} \mathrm{~km}^{2} \mathrm{yr}^{-1}$ in MIROC-ESM to $-50 \times 10^{3} \mathrm{~km}^{2} \mathrm{yr}^{-1}$ in JULES (Fig. 9a). The average loss rate of NSPA across the models $\left(-23 \pm 23 \times 10^{3} \mathrm{~km}^{2} \mathrm{yr}^{-1}\right)$ is smaller than in the previous estimations of Burke et al. (2013) and Slater and Lawrence (2013). For example, the loss rate of NSPA was estimated at $-81 \times 10^{3}$ to $-55 \times 10^{3} \mathrm{~km}^{2} \mathrm{yr}^{-1}$ during the period 1967-2000 by JULES offline simulations with different climate-forcing data sets (Burke et al., 2013). The ranges of loss rate of NSPA in BONA, BOEU, and BOAS across the models are $-16.6 \times 10^{3}$ to $2.2 \times 10^{3} \mathrm{~km}^{2} \mathrm{yr}^{-1},-4.0 \times 10^{3}$ to $0.0 \times 10^{3} \mathrm{~km}^{2} \mathrm{yr}^{-1}$, and $-34.2 \times 10^{3}$ to $-1.1 \times 10^{3} \mathrm{~km}^{2} \mathrm{yr}^{-1}$, respectively (Fig. 9). This is consistent with the observed permafrost degradation (decrease in thickness) in these regions (Vaughan et al., 2013).

The retreat rate of NSPA is not correlated significantly with the initial NSPA of each model $(R=-0.30, P=$ 0.438), implying that the initial state of the models is less important than their response to climate change in determining NSPA loss rates. Contrary to the small effect of initial NSPA, the trend of summer $T_{\mathrm{s}}$ at $1 \mathrm{~m}$ is found to be strongly correlated with NSPA loss rates across the models of the ensemble. Figure 9 shows that the trend of summer $T_{\mathrm{s}}$ at $1 \mathrm{~m}$ can explain $73 \%$ of the differences in NSPA loss rates between models. The sensitivity of NSPA loss rate to summer $\dot{T}_{\mathrm{s}}$ at $1 \mathrm{~m}$ is estimated to be $-2.80 \pm 0.67$ million $\mathrm{km}^{2}{ }^{\circ} \mathrm{C}^{-1}$, based on the linear regression between the loss rate of NSPA and the trend of summer $T_{\mathrm{S}}$ at $1 \mathrm{~m}$ across the nine models (Fig. 9). For the BONA, BOEU, and BOAS sub-regions, the sensitivities of NSPA loss rate to summer $\dot{T}_{\mathrm{s}}$ at $1 \mathrm{~m}$ are $-0.74 \pm 0.10$, $-0.09 \pm 0.03$, and $-1.74 \pm 0.59$ million $\mathrm{km}^{2}{ }^{\circ} \mathrm{C}^{-1}$, respectively (Fig. 9). The sensitivity of future total NSPA changes to $T_{\mathrm{a}}$ over pan-Arctic regions was estimated to be $-1.67 \pm 0.7$ million $\mathrm{km}^{2}{ }^{\circ} \mathrm{C}^{-1}$, ranging from 0.2 to 
3.5 million $\mathrm{km}^{2}{ }^{\circ} \mathrm{C}^{-1}$ in the CMIP5 multi-model ensemble (Slater and Lawrence, 2013; Koven et al., 2013). The average of trends in summer $T_{\mathrm{S}}$ at $1 \mathrm{~m}$ is only $70 \%(43-$ $100 \%)$ of $\dot{T}_{\mathrm{a}}$ in the nine models, so the sensitivity of total NSPA to $T_{\mathrm{a}}$ over boreal regions in the nine models is about $-2.00 \pm 0.47$ million $\mathrm{km}^{2}{ }^{\circ} \mathrm{C}^{-1}$, which is larger than that from the the CMIP5 multi-model ensemble but comparable within the uncertainties of each estimate (Slater and Lawrence, 2013). Six out of the nine models of this study were also used as land surface schemes of the coupled CMIP5 models, but possibly for different versions.

A mean positive trend of summer LWDR of $0.073 \pm 0.030$ and $0.210 \pm 0.027 \mathrm{~W} \mathrm{~m}^{2} \mathrm{yr}^{-1}$ over boreal regions from 1960 to 2000 is derived from the CRUNCEP and WATCH data sets, respectively. We applied this trend of LWDR to an emerging constraint on summer $T_{\mathrm{S}}$ trends from the relationship between the trend of summer LWDR and the trend of summer $T_{\mathrm{S}}$ at $1 \mathrm{~m}$ (Fig. S7). This approach constrains the trend of summer $T_{\mathrm{S}}$ to $0.014 \pm 0.004{ }^{\circ} \mathrm{C} \mathrm{yr}^{-1}$ with CRUN$\mathrm{CEP}$ and to $0.027 \pm 0.004{ }^{\circ} \mathrm{Cyr}^{-1}$ with WATCH. The uncertainty is reduced by $50 \%$ from the prior range including different models and different forcings. A total NSPA loss rate of $39 \pm 14 \times 10^{3} \mathrm{~km}^{2} \mathrm{yr}^{-1}$ can be constrained by multiplying the sensitivity of total NSPA loss rate to summer $\dot{T}_{\mathrm{s}}$ at $1 \mathrm{~m}\left(-2.80 \pm 0.67\right.$ million $\left.\mathrm{km}^{2}{ }^{\circ} \mathrm{C}^{-1}\right)$ by the trend of $T_{\mathrm{s}}$ at $1 \mathrm{~m}$, itself empirically estimated by LWDR during 1960-2000 from CRUNCEP $\left(0.014 \pm 0.004{ }^{\circ} \mathrm{C} \mathrm{yr}^{-1}\right)$. The constrained loss rate of NSPA over BONA, BOEU, and BOAS based upon the CRUNCEP LWDR from 1960 to 2000 is $11 \pm 5 \times 10^{3}, 1 \pm 1 \times 10^{3}$, and $25 \pm 11 \times 10^{3} \mathrm{~km}^{2} \mathrm{yr}^{-1}$, respectively. Similarly, if WATCH LWDR is used to constrain the NSPA loss rate, the total NSPA loss rate is $75 \pm 14 \times 10^{3} \mathrm{~km}^{2} \mathrm{yr}^{-1}$, and the loss rate of NSPA over BONA, BOEU, and BOAS is estimated to be $28 \pm 10 \times 10^{3}$, $2 \pm 1 \times 10^{3}$, and $39 \pm 19 \times 10^{3} \mathrm{~km}^{2} \mathrm{yr}^{-1}$, respectively. The southern boundary of the discontinuous permafrost zone has been observed to shift northward during recent decades (Vaughan et al., 2013), which is generally consistent with the simulations reported in this study. The larger warming rate and higher sensitivity of NSPA loss to $T_{\mathrm{S}}$ over BOAS could explain the reason for significant degradation of permafrost over BOAS compared to the other boreal regions (Vaughan et al., 2013). The larger permafrost degradation rate in BOAS than that in BONA may have larger effects on changes in vegetation distribution and growth, and permafrost carbon in these two regions, and it can be quantified in future studies. Obviously, there is a large difference in constrained NSPA between CRUNCEP and WATCH. In the future, long-term climate reanalysis including radiation evaluated against sites with long-term radiation measurements (http://www.geba.ethz.ch) would be extremely useful for land surface models to provide improved estimate of NSPA.

\section{Conclusions}

In this study, trends of soil temperature $\left(T_{\mathrm{S}}\right)$ over boreal regions from nine process-based models were analyzed for the past 40 years. All models produce a warming of $T_{\mathrm{s}}$, but the trends of $T_{\mathrm{s}}$ at $20 \mathrm{~cm}$ depth range from $0.010 \pm 0.003^{\circ} \mathrm{C} \mathrm{yr}^{-1}$ (CoLM) to $0.031 \pm 0.005^{\circ} \mathrm{C} \mathrm{yr}^{-1}$ (UVic) during $1960-2000$. Most models show a smaller increase of $T_{\mathrm{s}}$ with deeper depth. Air temperature $\left(T_{\mathrm{a}}\right)$ and LWDR are found to be the predominant drivers of the increase in $T_{\mathrm{S}}$ averaged across large spatial scales. The relative contribution of $T_{\mathrm{a}}$ and LWDR trends to the increase of $T_{\mathrm{S}}$ is, however, different across the models. Note that the relative contribution of LWDR is based on only two models in this study, and this needs further investigation. The total uncertainty of the trend of $T_{\mathrm{S}}$ at $20 \mathrm{~cm}$ is decomposed into the uncertainty contributed by uncertain climate-forcing data sets $\left(0.021 \pm 0.008^{\circ} \mathrm{C} \mathrm{yr}^{-1}\right)$ and the uncertainty reflecting model structure $\left(0.012 \pm 0.001{ }^{\circ} \mathrm{C} \mathrm{yr}^{-1}\right)$. The NSPA loss rate is significantly correlated among the model results with the simulated trend of $T_{\mathrm{S}}$ at $1 \mathrm{~m}$, with a linear sensitivity of total NSPA loss rate to summer trend of $T_{\mathrm{S}}\left(\dot{T}_{\mathrm{S}}\right)$ at $1 \mathrm{~m}$ of $-2.80 \pm 0.67$ million $\mathrm{km}^{2}{ }^{\circ} \mathrm{C}^{-1}$. Based on LWDR from CRUNCEP and WATCH data, the total NSPA decrease is estimated to be $39 \pm 14 \times 10^{3}-75 \pm 14 \times 10^{3} \mathrm{~km}^{2} \mathrm{yr}^{-1}$ from 1960 to 2000 . The constraint method used in this study could be applied to estimate historical and future permafrost degradation rate, and further to quantify the permafrost carbon loss by a permafrost carbon distribution map (Hugelius et al., 2014).

Given that meteorological stations are sparse in the cold permafrost regions, especially in Siberia and other unpopulated land in the north, the gridded climate products over high-latitude regions have a large uncertainty as well (Mitchell and Jones, 2005; Rawlins et al., 2010; Weedon et al., 2011). This large uncertainty could propagate into simulated permafrost dynamics and feedbacks. More sites are needed in high-latitude regions for reducing the climate uncertainty. Future model intercomparisons on permafrost dynamics should investigate the full uncertainty by conducting simulations for multiple climate-forcing data sets. Since the beginning of the satellite era, microwave emissivity data related to land surface temperature have become increasingly available (e.g., Smith et al., 2004). These images could be used to independently evaluate soil surface temperature in models on a large scale or be integrated in ground temperature models (e.g., Westermann et al., 2015), although they have their own uncertainties. In addition, many complex processes affect permafrost thermal dynamics in the models, such as soil organic insulation effects, snow insulation effects, and soil freeze-thaw cycles; it is valuable to evaluate the uncertainty of each process effects on soil thermal dynamic simulations based on site measurements. This could be helpful for reducing permafrost simulation uncertainty. 


\section{The Supplement related to this article is available online at doi:10.5194/tc-10-179-2016-supplement.}

Acknowledgements. This study has been supported by the PAGE21 project, funded by the European Commission FP7-ENV-2011 (grant agreement no. 282700), and has been developed as part of the modeling integration team of the Permafrost Carbon Network (PCN, www.permafrostcarbon.org), funded by the National Science Foundation. Any use of trade, firm, or product names is for descriptive purposes only and does not imply endorsement by the US Government. B. Decharme and C. Delire were supported by the French Agence Nationale de la Recherche under agreement ANR-10-CEPL-012-03.

Edited by: T. Bolch

\section{References}

Adam, J. C., Clark, E. A., Lettenmaier, D. P., and Wood, E. F.: Correction of Global Precipitation Products for Orographic Effects, J. Climate, 19, 15-38, doi:10.1175/jcli3604.1, 2006.

Alexeev, V. A., Nicolsky, D. J., Romanovsky, V. E., and Lawrence, D. M.: An evaluation of deep soil configurations in the CLM3 for improved representation of permafrost, Geophys. Res. Lett., 34, L09502, doi:10.1029/2007g1029536, 2007.

Avis, C. A., Weaver, A. J., and Meissner, K. J.: Reduction in areal extent of high-latitude wetlands in response to permafrost thaw, Nature Geosci., 4, 444-448, 2011.

Best, M. J., Pryor, M., Clark, D. B., Rooney, G. G., Essery, R .L. H., Ménard, C. B., Edwards, J. M., Hendry, M. A., Porson, A., Gedney, N., Mercado, L. M., Sitch, S., Blyth, E., Boucher, O., Cox, P. M., Grimmond, C. S. B., and Harding, R. J.: The Joint UK Land Environment Simulator (JULES), model description Part 1: Energy and water fluxes, Geosci. Model Dev., 4, 677-699, doi:10.5194/gmd-4-677-2011, 2011.

Bohn, T. J., Podest, E., Schroeder, R., Pinto, N., McDonald, K. C., Glagolev, M., Filippov, I., Maksyutov, S., Heimann, M., Chen, X., and Lettenmaier, D. P.: Modeling the large-scale effects of surface moisture heterogeneity on wetland carbon fluxes in the West Siberian Lowland, Biogeosciences, 10, 6559-6576, doi:10.5194/bg-10-6559-2013, 2013.

Bonfils, C. J. W., Phillips, T. J., Lawrence, D. M., Cameron-Smith, P., Riley, W. J., and Subin, Z. M.: On the influence of shrub height and expansion on northern high latitude climate, Environ. Res. Lett., 7, 015503, doi:10.1088/1748-9326/7/1/015503, 2012.

Brown, J., Ferrians, Jr., O. J., Heginbottom, J. A., and Melnikov, E. S.: Circum-Arctic map of permafrost and ground-ice conditions, Boulder, CO, National Snow and Ice Data Center/World Data Center for Glaciology, Digital Media, 1998.

Burke, E., Dankers, R., Jones, C., and Wiltshire, A.: A retrospective analysis of pan Arctic permafrost using the JULES land surface model, Clim. Dyn., 41, 1025-1038, doi:10.1007/s00382012-1648-x, 2013.

Clark, D. B., Mercado, L. M., Sitch, S., Jones, C. D., Gedney, N., Best, M. J., Pryor, M., Rooney, G. G., Essery, R. L. H., Blyth, E.,
Boucher, O., Harding, R. J., Huntingford, C., and Cox, P. M.: The Joint UK Land Environment Simulator (JULES), model description - Part 2: Carbon fluxes and vegetation dynamics, Geosci. Model Dev., 4, 701-722, doi:10.5194/gmd-4-701-2011, 2011.

Dai, Y., Zeng, X., Dickinson, R. E., Baker, I., Bonan, G. B., Bosilovich, M. G., Denning, A. S., Dirmeyer, P. A., Houser, P. R., Niu, G., Oleson, K. W., Schlosser, C. A., and Yang, Z.-L.: The Common Land Model, B. Am. Meteorol. Soc., 84, 1013-1023, doi:10.1175/bams-84-8-1013, 2003.

Dai, Y., Dickinson, R. E., and Wang, Y.-P.: A Two-Big-Leaf Model for Canopy Temperature, Photosynthesis, and Stomatal Conductance, J. Climate, 17, 2281-2299, doi:10.1175/15200442(2004)017<2281:atmfct>2.0.co;2, 2004.

Decharme, B., Boone, A., Delire, C., and Noilhan, J.: Local evaluation of the Interaction between Soil Biosphere Atmosphere soil multilayer diffusion scheme using four pedotransfer functions, J. Geophys. Res.-Atmos., 116, D20126, doi:10.1029/2011jd016002, 2011.

Decharme, B., Martin, E., and Faroux, S.: Reconciling soil thermal and hydrological lower boundary conditions in land surface models, J. Geophys. Res.-Atmos., 118, 7819-7834, doi:10.1002/jgrd.50631, 2013.

Elberling, B., Michelsen, A., Schadel, C., Schuur, E. A. G., Christiansen, H. H., Berg, L., Tamstorf, M. P., and Sigsgaard, C.: Long-term $\mathrm{CO}_{2}$ production following permafrost thaw, Nature Clim. Change, 3, 890-894, doi:10.1038/nclimate1955, 2013.

Field, C. B., Jackson, R. B., and Mooney, H. A.: Stomatal responses to increased $\mathrm{CO}_{2}$ : implications from the plant to the global scale, Plant, Cell \& Environment, 18, 1214-1225, doi:10.1111/j.13653040.1995.tb00630.x, 1995.

Gouttevin, I., Krinner, G., Ciais, P., Polcher, J., and Legout, C.: Multi-scale validation of a new soil freezing scheme for a landsurface model with physically-based hydrology, The Cryosphere, 6, 407-430, doi:10.5194/tc-6-407-2012, 2012.

Gruber, S.: Derivation and analysis of a high-resolution estimate of global permafrost zonation, The Cryosphere, 6, 221-233, doi:10.5194/tc-6-221-2012, 2012.

Harris, I., Jones, P. D., Osborn, T. J., and Lister, D. H.: Updated high-resolution grids of monthly climatic observations - the CRU TS3.10 Dataset, Int. J. Climatol., 34, 623-642, doi:10.1002/joc.3711, 2014.

Hugelius, G., Strauss, J., Zubrzycki, S., Harden, J. W., Schuur, E. A. G., Ping, C.-L., Schirrmeister, L., Grosse, G., Michaelson, G. J., Koven, C. D., O’Donnell, J. A., Elberling, B., Mishra, U., Camill, P., Yu, Z., Palmtag, J., and Kuhry, P.: Estimated stocks of circumpolar permafrost carbon with quantified uncertainty ranges and identified data gaps, Biogeosciences, 11, 6573-6593, doi:10.5194/bg-11-6573-2014, 2014.

Ji, D., Wang, L., Feng, J., Wu, Q., Cheng, H., Zhang, Q., Yang, J., Dong, W., Dai, Y., Gong, D., Zhang, R.-H., Wang, X., Liu, J., Moore, J. C., Chen, D., and Zhou, M.: Description and basic evaluation of Beijing Normal University Earth System Model (BNU-ESM) version 1, Geosci. Model Dev., 7, 2039-2064, doi:10.5194/gmd-7-2039-2014, 2014.

Kalnay, E., Kanamitsu, M., Kistler, R., Collins, W., Deaven, D., Gandin, L., Iredell, M., Saha, S., White, G., Woollen, J., Zhu, Y., Leetmaa, A., Reynolds, R., Chelliah, M., Ebisuzaki, W., Higgins, W., Janowiak, J., Mo, K. C., Ropelewski, C., Wang, J., Jenne, R., and Joseph, D.: The NCEP/NCAR 40-Year Reanalysis 
Project, B. Am. Meteorol. Soc., 77, 437-471, doi:10.1175/15200477(1996)077<0437:tnyrp>2.0.co;2, 1996.

Khvorostyanov, D. V., Ciais, P., Krinner, G., Zimov, S. A., Corradi, C., and Guggenberger, G.: Vulnerability of permafrost carbon to global warming. Part II: sensitivity of permafrost carbon stock to global warming, Tellus B, 60, 265-275, doi:10.1111/j.16000889.2007.00336.x, 2008.

Koven, C., Friedlingstein, P., Ciais, P., Khvorostyanov, D., Krinner, G., and Tarnocai, C.: On the formation of high-latitude soil carbon stocks: Effects of cryoturbation and insulation by organic matter in a land surface model, Geophys. Res. Lett., 36, L21501, doi:10.1029/2009g1040150, 2009.

Koven, C. D., Ringeval, B., Friedlingstein, P., Ciais, P., Cadule, P., Khvorostyanov, D., Krinner, G., and Tarnocai, C.: Permafrost carbon-climate feedbacks accelerate global warming, P. Natl. Acad. Sci. USA, 14769-14774, doi:10.1073/pnas.1103910108, 2011.

Koven, C. D., Riley, W. J., and Stern, A.: Analysis of Permafrost Thermal Dynamics and Response to Climate Change in the CMIP5 Earth System Models, J. Climate, 26, 1877-1900, doi:10.1175/jcli-d-12-00228.1, 2013.

Koven, C. D., Schuur, E. A. G., Schädel, C., Bohn, T. J., Burke, E. J., Chen, G., Chen, X., Ciais, P., Grosse, G., Harden, J. W., Hayes, D. J., Hugelius, G., Jafarov, E. E., Krinner, G., Kuhry, P., Lawrence, D. M., MacDougall, A. H., Marchenko, S. S., McGuire, A. D., Natali, S. M., Nicolsky, D. J., Olefeldt, D., Peng, S., Romanovsky, V. E., Schaefer, K. M., Strauss, J., Treat, C. C., and Turetsky, M.: A simplified, data-constrained approach to estimate the permafrost carbon-climate feedback, Philos. Trans. A. Math. Phys. Eng. Sci., 373, doi:10.1098/rsta.2014.0423, 2015.

Krinner, G., Viovy, N., de Noblet-Ducoudré, N., Ogée, J., Polcher, J., Friedlingstein, P., Ciais, P., Sitch, S., and Prentice, I. C.: A dynamic global vegetation model for studies of the coupled atmosphere-biosphere system, Global Biogeochem. Cy., 19, GB1015, doi:10.1029/2003gb002199, 2005.

Lawrence, D. and Slater, A.: Incorporating organic soil into a global climate model, Clim. Dyn., 30, 145-160, doi:10.1007/s00382007-0278-1, 2008.

Lawrence, D. M., Slater, A. G., Romanovsky, V. E., and Nicolsky, D. J.: Sensitivity of a model projection of near-surface permafrost degradation to soil column depth and representation of soil organic matter, J. Geophys. Res.-Earth, 113, F02011, doi:10.1029/2007jf000883, 2008.

Lee, H., Swenson, S. C., Slater, A. G., and Lawrence, D. M.: Effects of excess ground ice on projections of permafrost in a warming climate, Environ. Res. Lett., 9, 124006, doi:10.1088/17489326/9/12/124006, 2014.

MacDougall, A. H., Avis, C. A., and Weaver, A. J.: Significant contribution to climate warming from the permafrost carbon feedback, Nature Geosci., 5, 719-721, doi:10.1038/ngeo1573, 2012.

McGuire, A. D., Anderson, L. G., Christensen, T. R., Dallimore, S., Guo, L., Hayes, D. J., Heimann, M., Lorenson, T. D., Macdonald, R. W., and Roulet, N.: Sensitivity of the carbon cycle in the Arctic to climate change, Ecol. Monogr., 79, 523-555, doi:10.1890/08-2025.1, 2009.

McGuire, A. D., Christensen, T. R., Hayes, D., Heroult, A., Euskirchen, E., Kimball, J. S., Koven, C., Lafleur, P., Miller, P. A., Oechel, W., Peylin, P., Williams, M., and Yi, Y.: An assessment of the carbon balance of Arctic tundra: comparisons among ob- servations, process models, and atmospheric inversions, Biogeosciences, 9, 3185-3204, doi:10.5194/bg-9-3185-2012, 2012.

Mitchell, T. D. and Jones, P. D.: An improved method of constructing a database of monthly climate observations and associated high-resolution grids, Int. J. Climatol., 25, 693-712, doi:10.1002/joc.1181, 2005.

Nicolsky, D., Romanovsky, V., Alexeev, V., and Lawrence, D.: Improved modeling of permafrost dynamics in a GCM land-surface scheme, Geophys. Res. Lett., 34, L08501, doi:10.1029/2007GL029525, 2007.

Oleson, K. W., Lawrence, D. M., Bonan, G. B., Drewniak, B., Huang, M., Koven, C. D., Levis, S., Li, F., Riley, W. J., Subin, Z. M., Swenson, S. C., Thornton, P. E., Bozbiyik, A., Fisher, R., Heald, C. L., Kluzek, E., Lamarque, J., Lawrence, P. J., Leung, L. R., Lipscomb, W., Muszala, S., Ricciuto, D. M., Sacks, W., Tang, J., and Yang, Z.: Technical Description of version 4.5 of the Community Land Model (CLM). P.O. Box 3000 BOULDER, COLORADO 80307-3000, National Center for Atmospheric Research, NCAR Technical Note \#NCAR/TN-503+STR, June 2013.

Osterkamp, T. E.: A thermal history of permafrost in Alaska. Proceedings of Eighth International Conference on Permafrost, Zurich, 863-868, 21-25 July 2003.

Osterkamp, T. E.: Characteristics of the recent warming of permafrost in Alaska, J. Geophys. Res.-Earth, 112, F02S02, doi:10.1029/2006jf000578, 2007.

Park, H., Sherstiukov. A. B., Fedorov, A. N., Polyakov, I. V., and Walsh, J. E.: An observation-based assessment of the influences of air temperature and snow depth on soil temperature in Russia, Environ. Res. Lett., 9, 064026, doi:10.1088/17489326/9/6/064026, 2014.

Qian, B., Gregorich, E. G., Gameda, S., Hopkins, D. W., and Wang, X. L.: Observed soil temperature trends associated with climate change in Canada, J. Geophys. Res.-Atmos., 116, D02106, doi:10.1029/2010jd015012, 2011.

Rawlins, M. A., Steele, M., Holland, M. M., Adam, J. C., Cherry, J. E., Francis, J. A., Groisman, P. Y., Hinzman, L. D., Huntington, T. G., Kane, D. L., Kimball, J. S., Kwok, R., Lammers, R. B., Lee, C. M., Lettenmaier, D. P., McDonald, K. C., Podest, E., Pundsack, J. W., Rudels, B., Serreze, M. C., Shiklomanov, A., Skagseth, O., Troy, T. J., Vorosmarty, C. J., Wensnahan, M., Wood, E. F., Woodgate, R., Yang, D. Q., Zhang, K., and Zhang, T. J.: Analysis of the Arctic System for Freshwater Cycle Intensification: Observations and Expectations, J. Climate, 23, 57155737, doi:10.1175/2010jcli3421.1, 2010.

Rawlins, M. A., McGuire, A. D., Kimball, J. S., Dass, P., Lawrence, D., Burke, E., Chen, X., Delire, C., Koven, C., MacDougall, A., Peng, S., Rinke, A., Saito, K., Zhang, W., Alkama, R., Bohn, T. J., Ciais, P., Decharme, B., Gouttevin, I., Hajima, T., Ji, D., Krinner, G., Lettenmaier, D. P., Miller, P., Moore, J. C., Smith, B., and Sueyoshi, T.: Assessment of model estimates of landatmosphere $\mathrm{CO}_{2}$ exchange across Northern Eurasia, Biogeosciences, 12, 4385-4405, doi:10.5194/bg-12-4385-2015, 2015.

Romanovsky, V. E., Sazonova, T. S., Balobaev, V. T., Shender, N. I., and Sergueev, D. O.: Past and recent changes in air and permafrost temperatures in eastern Siberia, Global Planet. Change, 56, 399-413, doi:10.1016/j.gloplacha.2006.07.022, 2007.

Romanovsky, V. E., Smith, S. L., and Christiansen, H. H.: Permafrost thermal state in the polar Northern Hemisphere during 
the international polar year 2007-2009: a synthesis, Permafrost Periglac., 21, 106-116, doi:10.1002/ppp.689, 2010.

Schädel, C., Schuur, E. A. G., Bracho, R., Elberling, B., Knoblauch, C., Lee, H., Luo, Y., Shaver, G. R., and Turetsky, M. R.: Circumpolar assessment of permafrost $\mathrm{C}$ quality and its vulnerability over time using long-term incubation data, Glob. Change Biol., 20, 641-652, doi:10.1111/gcb.12417, 2014.

Schaefer, K., Zhang, T., Bruhwiler, L., and Barrett, A. P.: Amount and timing of permafrost carbon release in response to climate warming, Tellus B, 63, 165-180, doi:10.1111/j.16000889.2011.00527.x, 2011.

Schneider von Deimling, T., Meinshausen, M., Levermann, A., Huber, V., Frieler, K., Lawrence, D. M., and Brovkin, V.: Estimating the near-surface permafrost-carbon feedback on global warming, Biogeosciences, 9, 649-665, doi:10.5194/bg-9-649-2012, 2012.

Schuur, E. A. G., Bockheim, J., Canadell, J. G., Euskirchen, E., Field, C. B., Goryachkin, S. V., Hagemann, S., Kuhry, P., Lafleur, P. M., Lee, H., Mazhitova, G., Nelson, F. E., Rinke, A., Romanovsky, V. E., Shiklomanov, N., Tarnocai, C., Venevsky, S., Vogel, J. G., and Zimov, S. A.: Vulnerability of Permafrost Carbon to Climate Change: Implications for the Global Carbon Cycle, BioScience, 58, 701-714, doi:10.1641/b580807, 2008.

Sheffield, J., Goteti, G., and Wood, E. F.: Development of a 50Year High-Resolution Global Dataset of Meteorological Forcings for Land Surface Modeling, J. Climate, 19, 3088-3111, doi:10.1175/jcli3790.1, 2006.

Slater, A. G. and Lawrence, D. M.: Diagnosing Present and Future Permafrost from Climate Models, J. Climate, 26, 5608-5623, doi:10.1175/jcli-d-12-00341.1, 2013.

Smith, B., Prentice, I. C., and Sykes, M. T.: Representation of vegetation dynamics in the modelling of terrestrial ecosystems: comparing two contrasting approaches within European climate space, Global Ecology and Biogeography, 10, 621-637, doi:10.1046/j.1466-822X.2001.t01-1-00256.x, 2001.

Smith, N. V., Saatchi, S. S., and Randerson, J. T.: Trends in high northern latitude soil freeze and thaw cycles from 1988 to 2002, J. Geophys. Res-Atmos., 109, D12101, doi:10.1029/2003JD004472, 2004.

Smith, S. L., Burgess, M. M., Riseborough, D., and Mark Nixon, F.: Recent trends from Canadian permafrost thermal monitoring network sites, Permafrost Periglac., 16, 19-30, doi:10.1002/ppp.511, 2005.

Smith, S. L., Romanovsky, V. E., Lewkowicz, A. G., Burn, C. R., Allard, M., Clow, G. D., Yoshikawa, K., and Throop, J.: Thermal state of permafrost in North America: a contribution to the international polar year, Permafrost Periglac., 21, 117-135, doi:10.1002/ppp.690, 2010.

Smith, S. L., Throop, J., and Lewkowicz, A. G.: Recent changes in climate and permafrost temperatures at forested and polar desert sites in northern Canada, Can. J. Earth Sci., 49, 914-924, doi:10.1139/e2012-019, 2012.

Stevens, M. B., Smerdon, J. E., González-Rouco, J. F., Stieglitz, M., and Beltrami, H.: Effects of bottom boundary placement on subsurface heat storage: Implications for climate model simulations, Geophys. Res. Lett., 34, L02702, doi:10.1029/2006g1028546, 2007.

Troy, T. J. and Wood, E. F.: Comparison and evaluation of gridded radiation products across northern Eurasia, Environ. Res. Lett., 4, 045008, doi:10.1088/1748-9326/4/4/045008, 2009. van Huissteden, J., Berrittella, C., Parmentier, F. J. W., Mi, Y., Maximov, T. C., and Dolman, A. J.: Methane emissions from permafrost thaw lakes limited by lake drainage, Nature Clim. Change, 1, 119-123, doi:10.1038/nclimate1101, 2011.

Vaughan, D. G., Comiso, J. C., Allison, I., Carrasco, J., Kaser, G., Kwok, R., Mote, P., Murray, T., Paul, F., Ren, J., Rignot, E., Solomina, O., Steffen, K., and Zhang, T.: Observations: Cryosphere, in: Climate Change 2013: The Physical Science Basis. Contribution of Working Group I to the Fifth Assessment Report of the Intergovernmental Panel on Climate Change, edited by: Stocker, T. F., Qin, D., Plattner, G.-K., Tignor, M., Allen, S. K., Boschung, J., Nauels, A., Xia, Y., Bex, V., and Midgley, P. M., Cambridge University Press, Cambridge, United Kingdom and New York, NY, USA, 317-382, doi:10.1017/CBO9781107415324.012, 2013.

Watanabe, S., Hajima, T., Sudo, K., Nagashima, T., Takemura, T., Okajima, H., Nozawa, T., Kawase, H., Abe, M., Yokohata, T., Ise, T., Sato, H., Kato, E., Takata, K., Emori, S., and Kawamiya, M.: MIROC-ESM 2010: model description and basic results of CMIP5-20c3m experiments, Geosci. Model Dev., 4, 845-872, doi:10.5194/gmd-4-845-2011, 2011.

Weedon, G. P., Gomes, S., Viterbo, P., Shuttleworth, W. J., Blyth, E., Österle, H., Adam, J. C., Bellouin, N., Boucher, O., and Best, M.: Creation of the WATCH Forcing Data and Its Use to Assess Global and Regional Reference Crop Evaporation over Land during the Twentieth Century, J. Hydrometeorol., 12, 823-848, doi:10.1175/2011jhm1369.1, 2011.

Weedon, G. P., Balsamo, G., Bellouin, N., Gomes, S., Best, M. J., and Viterbo, P.: The WFDEI meteorological forcing data set: WATCH Forcing Data methodology applied to ERAInterim reanalysis data, Water Resour. Res., 50, 7505-7514, doi:10.1002/2014wr015638, 2014.

Wei, Y., Liu, S., Huntzinger, D. N., Michalak, A. M., Viovy, N., Post, W. M., Schwalm, C. R., Schaefer, K., Jacobson, A. R., Lu, C., Tian, H., Ricciuto, D. M., Cook, R. B., Mao, J., and Shi, X.: The North American Carbon Program Multi-scale Synthesis and Terrestrial Model Intercomparison Project - Part 2: Environmental driver data, Geosci. Model Dev., 7, 2875-2893, doi:10.5194/gmd-7-2875-2014, 2014.

Westermann, S., Østby, T. I., Gisnås, K., Schuler, T. V., and Etzelmüller, B.: A ground temperature map of the North Atlantic permafrost region based on remote sensing and reanalysis data, The Cryosphere, 9, 1303-1319, doi:10.5194/tc-9-13032015, 2015.

Willmott, C. J. and Matsuura, K.: Terrestrial Air Temperature and Precipitation: Monthly and Annual Time Series (1950-1999), available at: http://climate.geog.udel.edu/ climate/html_pages/ README.ghcn_ts2.html (last access: 19 December 2014), 2001.

Zhang, T., Barry, R., Gilichinsky, D., Bykhovets, S. S., Sorokovikov, V. A., and Ye, J.: An Amplified Signal of Climatic Change in Soil Temperatures during the Last Century at Irkutsk, Russia, Climatic Change, 49, 41-76, doi:10.1023/a:1010790203146, 2001. 